\title{
المواساة الاجتماعية وعلاقتها بالتحمل النفسي للأحداث الصدمية الإرهابية في المجتمع العراقي
}

أ.م.د. علي عبد الكاظم عجه الشمري

\section{الفصل الأول}

الإطار العام للبحث

أولاًا-مشكلة البحث وأهميته:

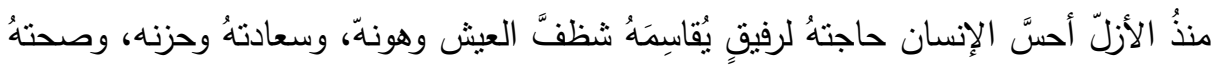

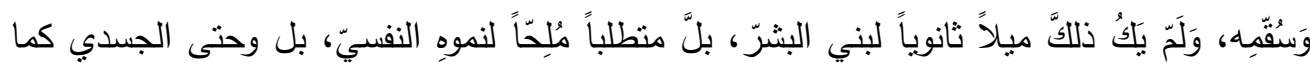

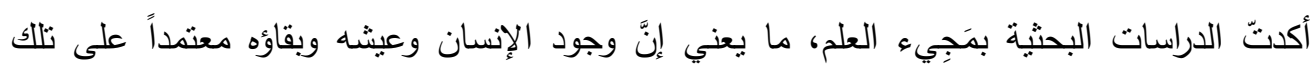

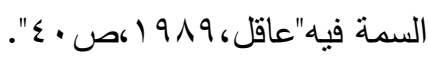

وقد ترسخت سمة الاجتماعية Sociality تلك لدى الإنسانّ وأثنتت تأثيرها بتلاحق الزمن، وهي

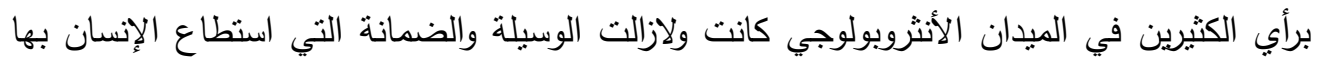

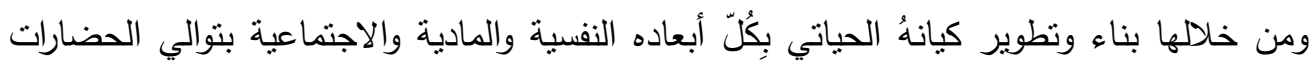

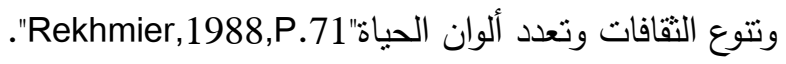

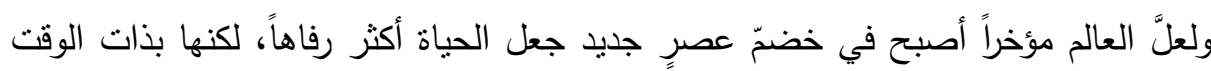

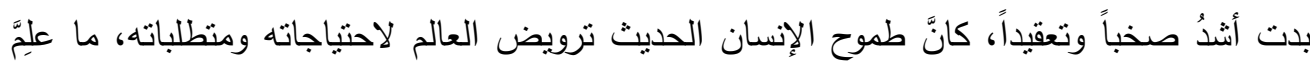

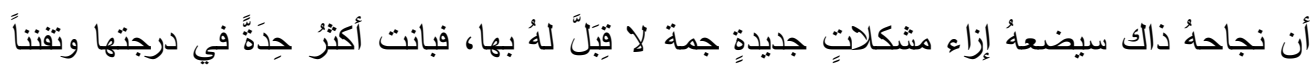

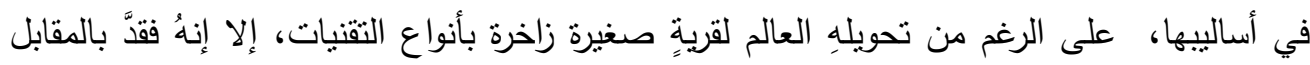

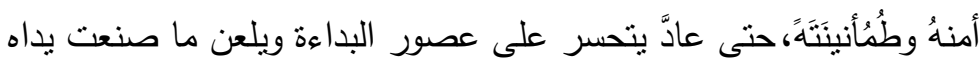




\section{مجلـــة كليـــة التربيـــة}

."McClellan,2006,P.501"

فلم يعد الأمر مقتصراً على ثتآكل الغلاف الغازي الذي حبا اللهُ بهِ الأرض جراء ههجية الإنسان

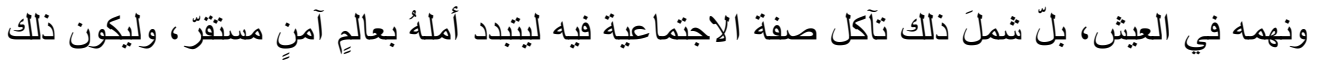

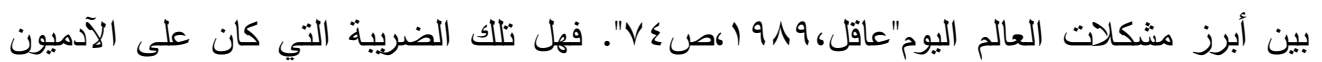

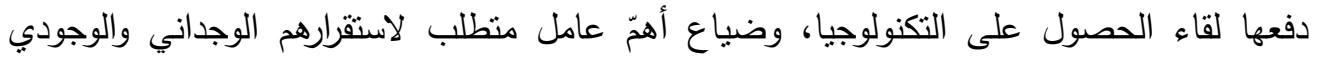

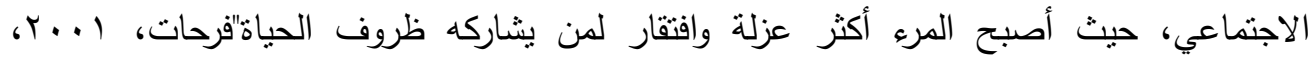
صV \"، خصوصاً وإن حاجته تلك تشتد في ظروف الأزمات كالمشكلات الأسرية أو فقدان الأعزة

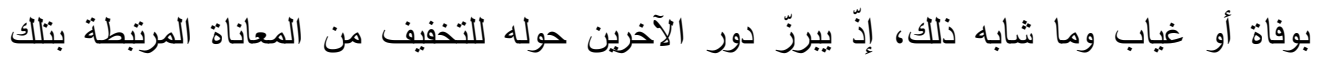

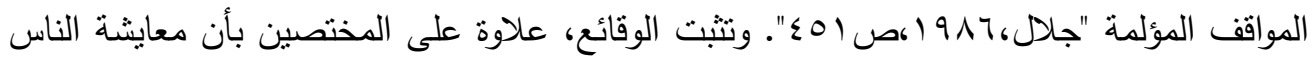

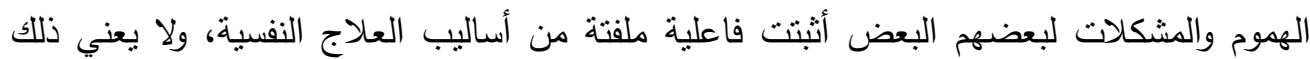

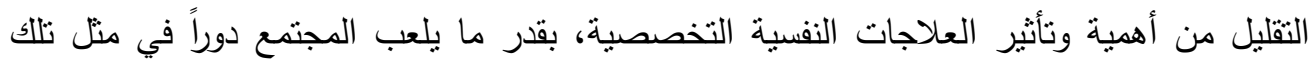

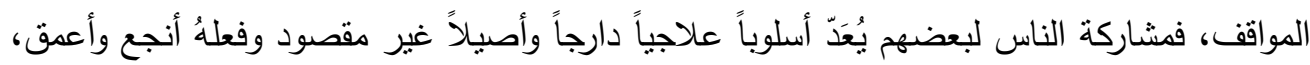

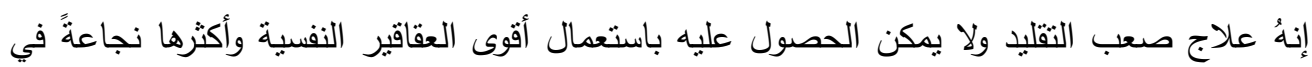

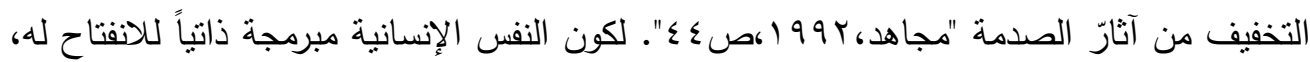

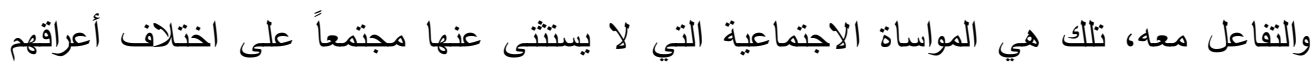

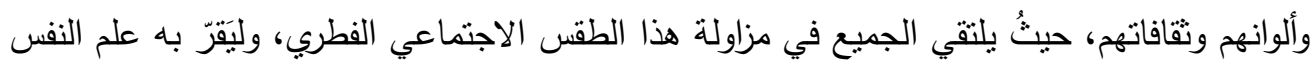

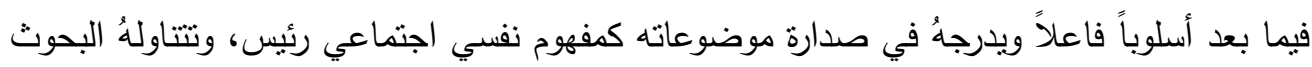
والدراسات بدرجة عالية من التركيز والأهية"

وهو ما ييرز تصاعد وتيرة البحث في تلك الظاهرة ودليل مرافقتها للحياة الإنسانية كصنوٍ واحد،

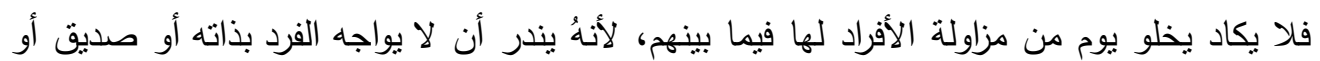

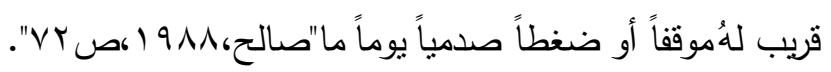

وتفيد الدراسات في مجال علم النفس العيادي بأنَّ عالم اليوم أصبح ميداناً للأحداث من

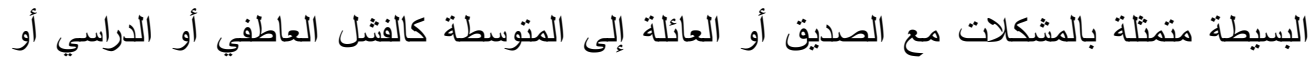




\section{مجــــة كليــة التربيــة}

المالي، حتى الكبرى متل فقدان عزيز ، أو خيانة صديق أو زوج أو جريمة ذات مساس بأمن البلد والمجتمع"Stewart,1992,P.72".

وَيُدِِجِ الباحثون في مجال الصحة النفسية والمجتمعية الأعراض والتبعات النفسية والاجتماعية الناجمة عن التعرض للحوادث الصدمية على منسلسل من الثندة في الدرجة والاستمرارية في الزمن، وتتمنل بالخلل في الحالة النفسية للفرد وسلوكه بعد الصدمة في مجالات الحئه الحياة المختلفة: العائلية والدراسية والمهنية والاجتماعية والقانونية، وتحديد مستويات الضرر في في الميلية فيادين أعلاه بالدقارنة بمستويات درجة حدة ونوعية الحوادث الصدمية "Gabbard,2000,P.242". ففي الدرجة

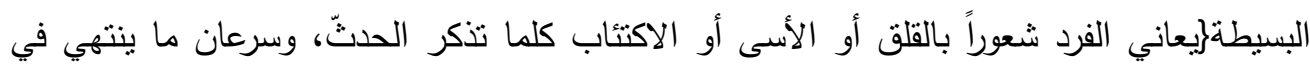

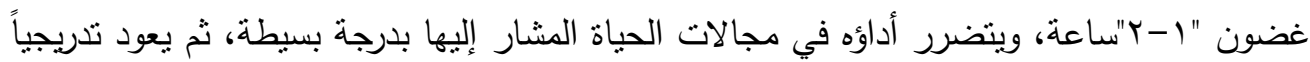

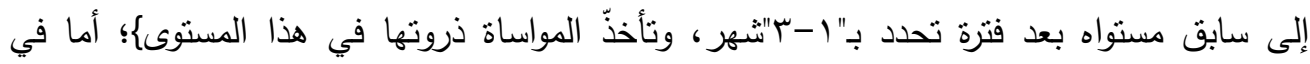

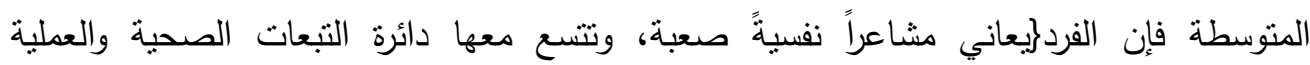

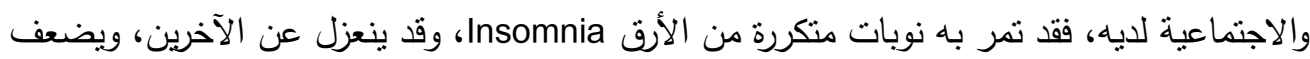

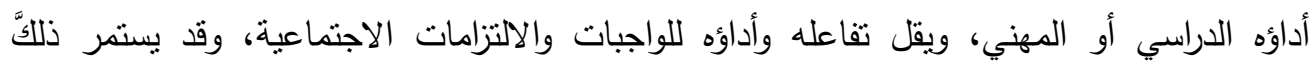

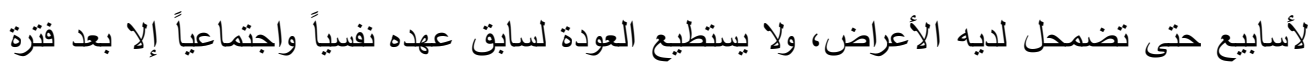

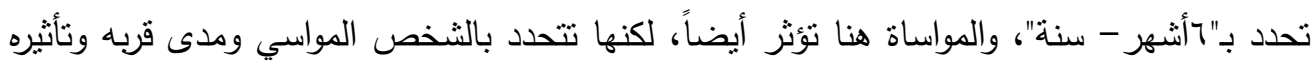

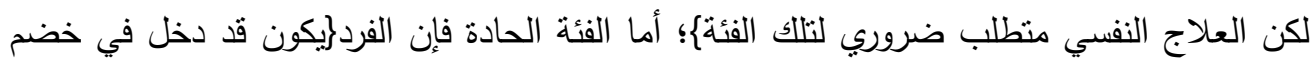

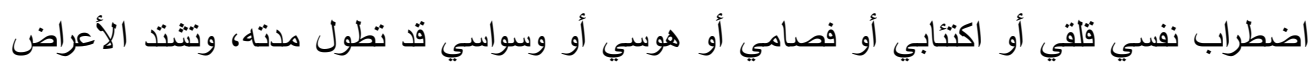

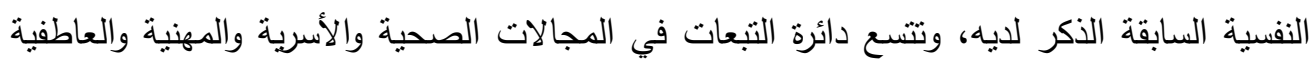

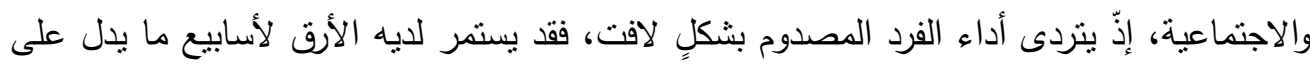

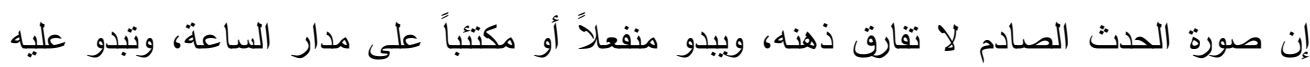

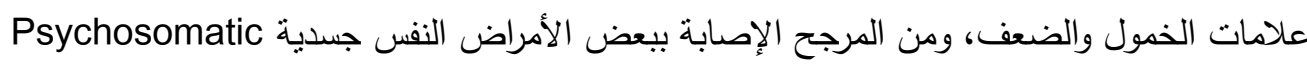

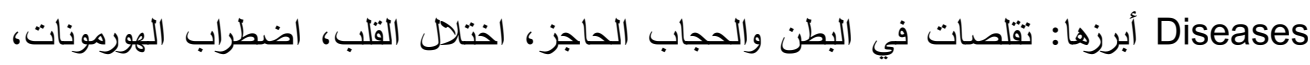

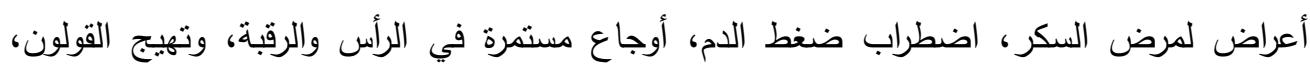

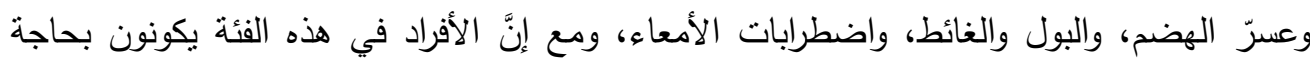

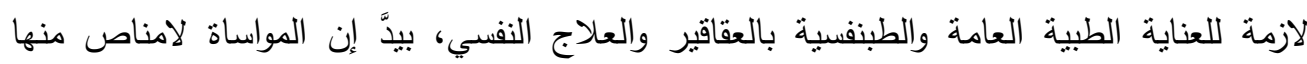


كعلاج ساند مكمل لا يمكن تجاهله، ويرجح أن تستمر الأعراض في تلاك الفئة بـ" ا - ب"سنة في حال

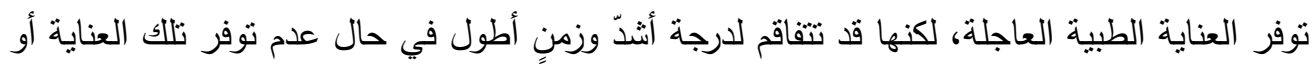
تأخرها توفر النابة

لإضافة لما تقدم فإنَّ المصادر تثشير إلى مشكلات سلوكية سلبية عدة ضمن التبعات الآتية

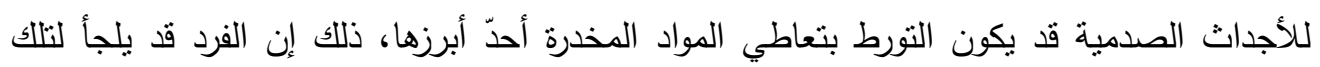

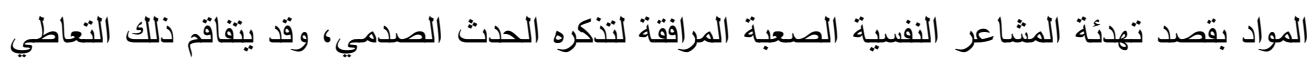

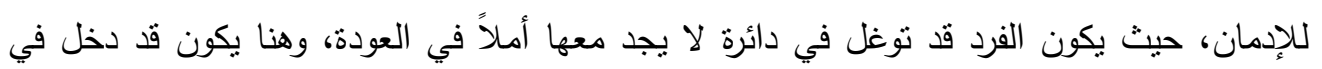

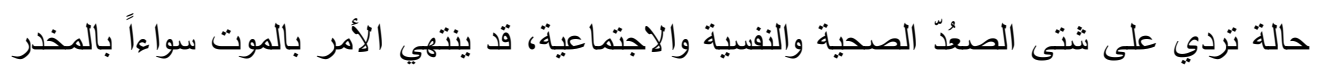

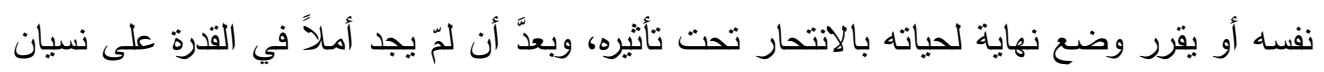

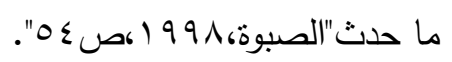

وتجدر الإثارة الى أنَّ المظاهر والتبعات المتقدمة الذكرّ تحصل للآلاف، بلّ الملايين عبر العالم

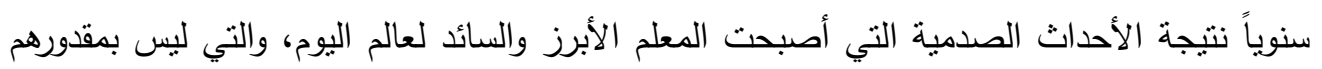

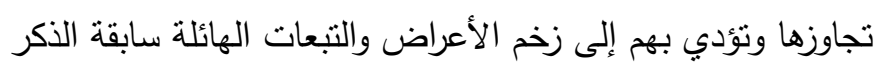

"كمال،911 (ك19407".

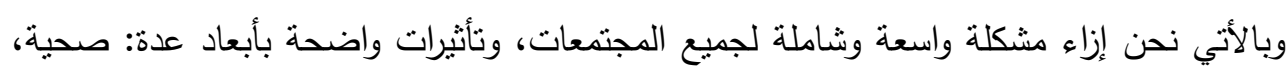

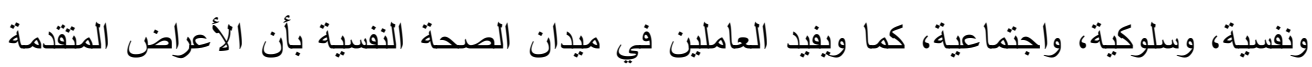

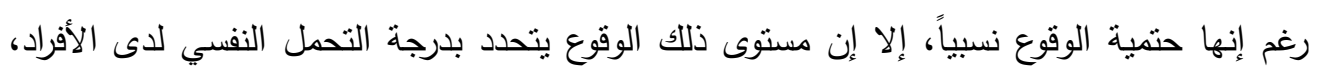

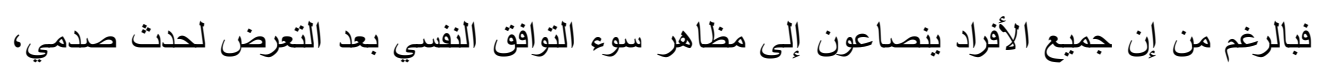
بره

بعد

يغادرونها

إنهم 


\section{مجلـــة كليـــة التربيـــة}

ة من الزمن، ثمَّ يعودوا إلى حالتهم النفسية والاجتماعية الاعتبادية ما قبل الصدمة

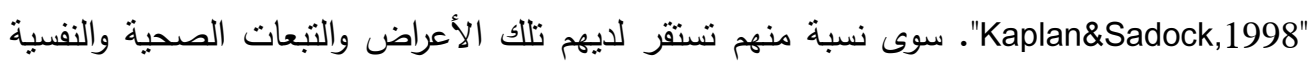

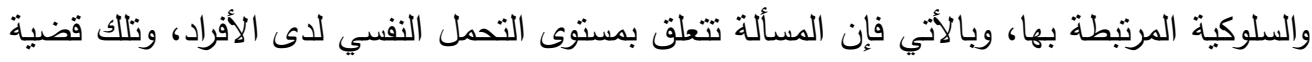

مفصلية في هذا السياق"Cohen\& Other,1985.P.277".

ولعلَّ آلية التحمل النفسي لدى البشر تلك هي الضمانة الفعلية لمعايشتهم الظروف والأزمات،

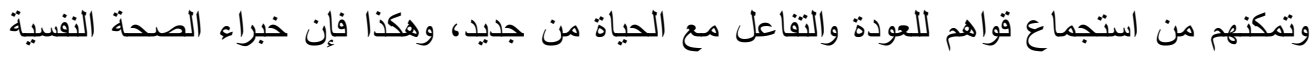
يحددون الميادين الدراسية والمهنية والعاطفية والاجتماعية كمكات Criteria لقياس مدى الضرر عند

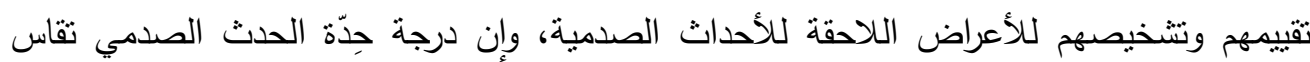

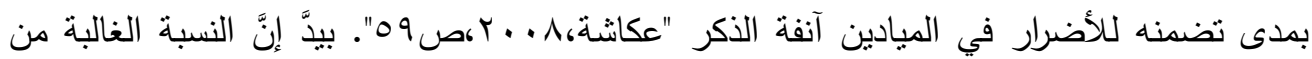

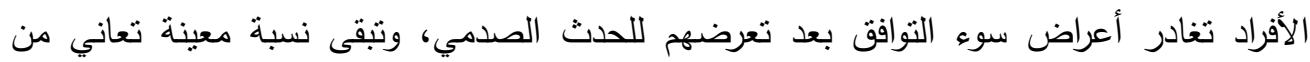

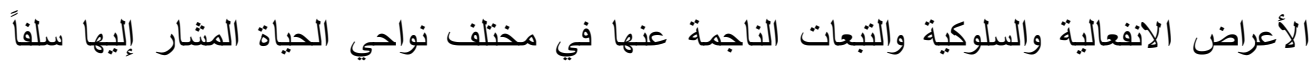

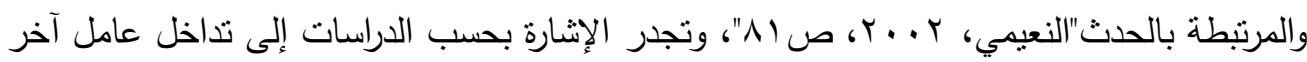
مضاف للتحمل النفسي، ويصفونهُ بالعامل الموضوعي كونهُ خارجي ولا يتعلق بطبيعة الفرد النفسية بالية يتمثل بـ نوعية الحدث الصدمي، ودرجة حدنه، والتبعات المادية والمعنوية المترتبة عليه، فيما إذا كانت مؤقتة أو ممكنة التعويض كإفلاس مالي أو فثل دراسي مقارنةً بققدان العزيز الذي يكون صعباً

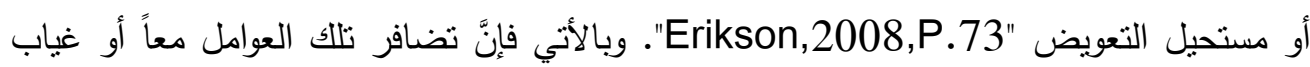
أحدها: أيّ تحمل نفسي ضعيف مع حدث صدمي غير قابل للتعويض قد يفاقم الأزمة النفسية،

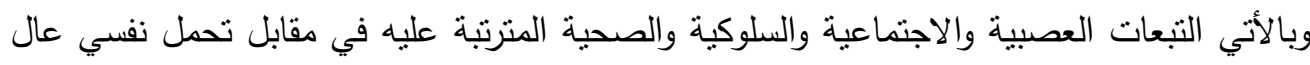
مع حدث صدمي بمختلف درجاته وتبعاته قد يشهد فترة بسيطة من الصعوبة النفسية وفاعلية أكثر للعلاجات المقدمة وأبرزها المواساة"Researchers Team, 2008.P.22". 
وتثتير الدراسات إلى إن المواساة الاجتماعية في العموم تلعب دوراً لا يمكن نكرانه أو تجاهله في

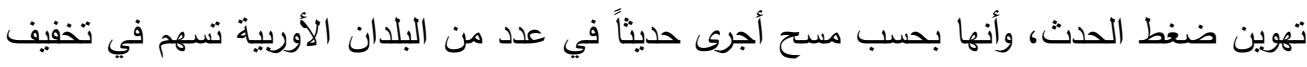

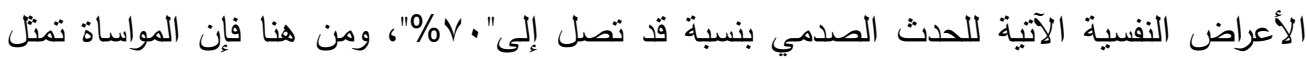

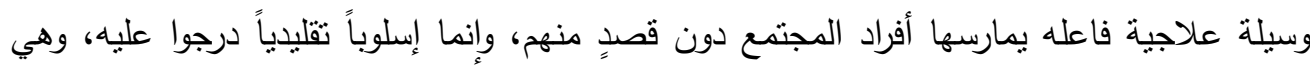
بذلك تمثل الضمانة التي تستتد إليها المجتمعات في علاج أفرادها، بل والعامل الجوهري في فاعلية

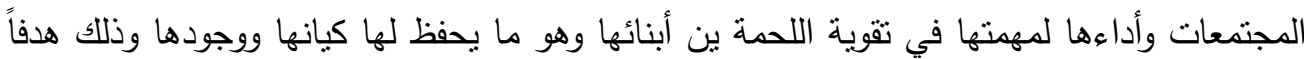

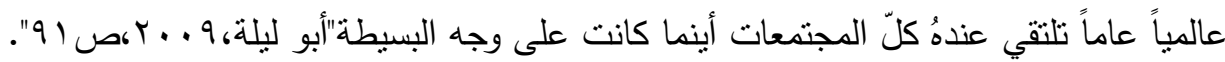
وبذلك فإن المواساة تأخذ طابعاً عالمياً على تتوع النقافات والعقائد والتقاليد، مع إنها تتراوح في درجة

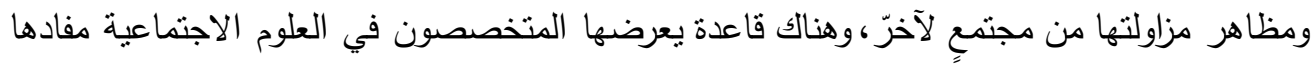

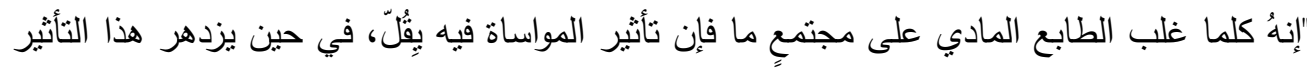

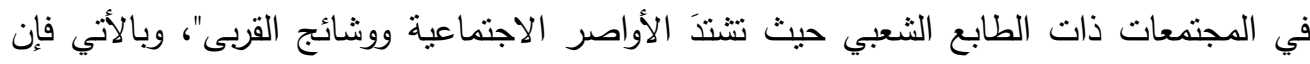
تلك مشكلة تواجه المواساة الاجتماعية كونها وسيلة اجتماعية علاجية فاعلة في تهيئة وتخفيف المعاناة من أعراض الأحداث الصدمية تئه

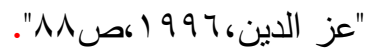

وتضيف الدراسات عاملاً أخراً في تداخله مع المواساة الاجتماعية، يتمتلُ بالأزمات الاجتماعية

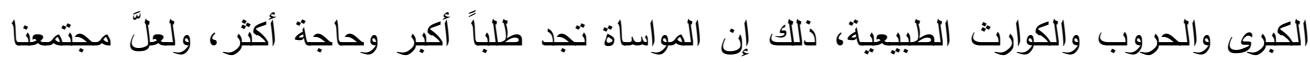

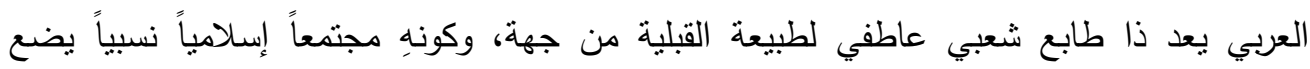

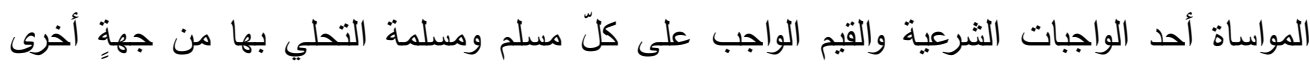

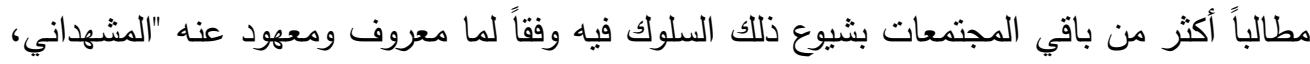

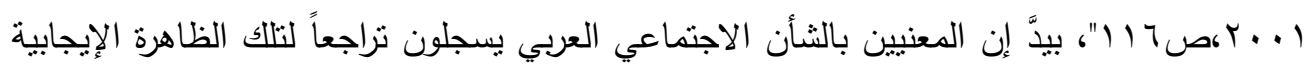

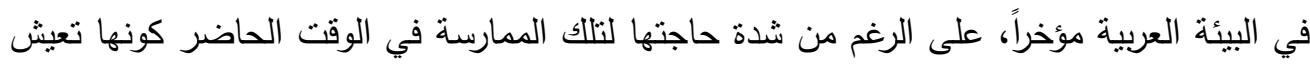

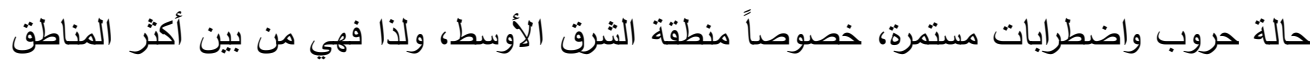

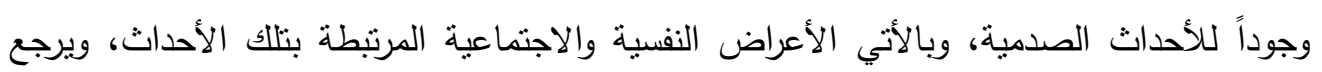
السبب برأي الباحثين ذاتهم إلى كثرة تلك الاضطرابات حتى أصبحت من الحالات اليومية شبه الإنيه 


\section{مجــــة كليــة التربيــة}

المعتادة ما أضعف اهتمام المجتمع بها، فضلاً عن صعوبات العيش وتدني الوضع الاقتصادي

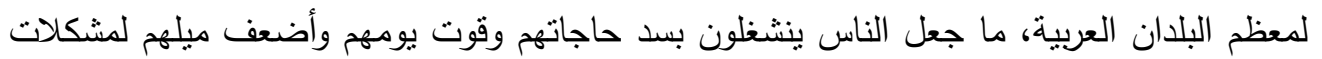

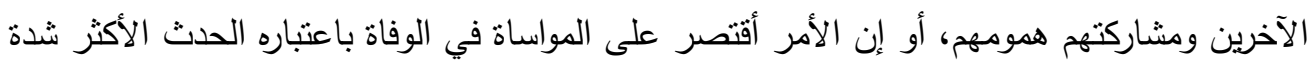

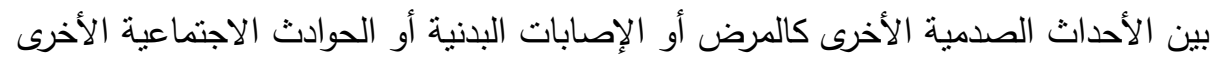

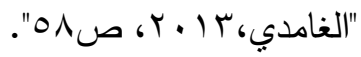

ولعلَّ المجتمع العراقي هو أحد أجزاء تللك المنطقة، ومشمولاً بما جرى ويجري عليها من أحداث

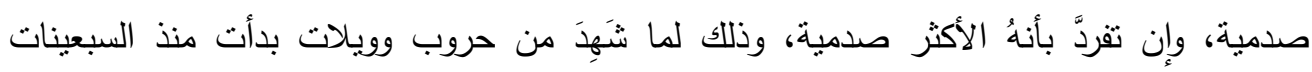
ولازالت مستمرة، الأمر الذي يجعله من أكثر شعوب المنطقة تضرراً بأحداثه الدامية، وبالأتي الأكثر

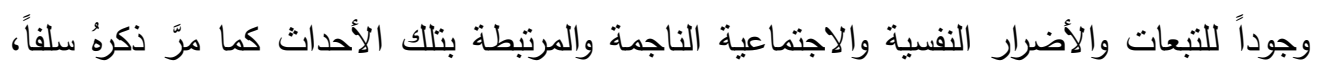

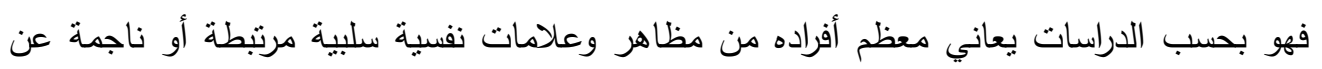

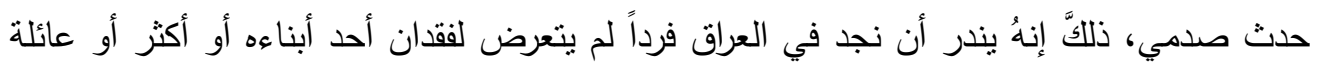

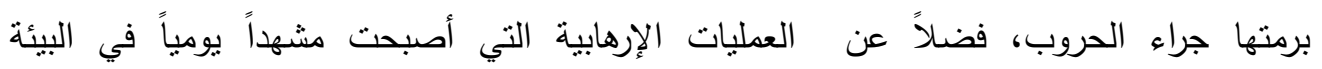

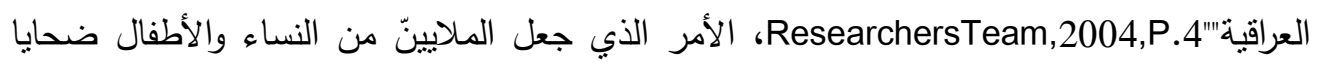

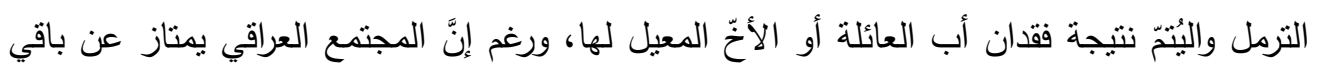

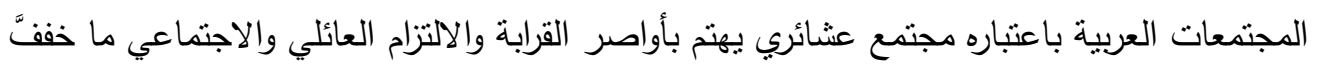

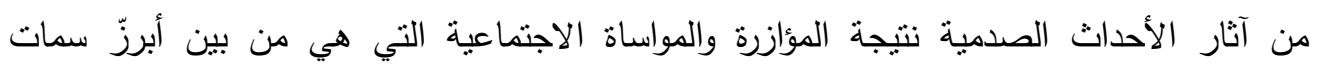

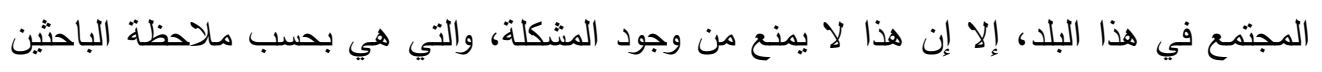

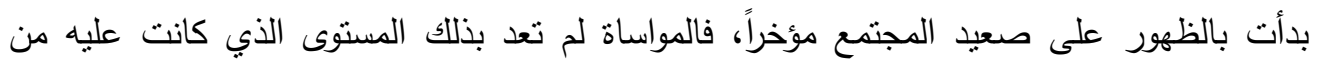

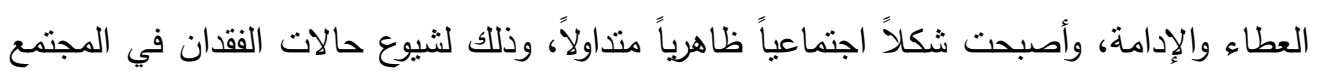
من جهة، وضغط العيش من جهة أخرى، وشيوع المفاهيم والقيم الخارجية نتيجة استخدام وسائل

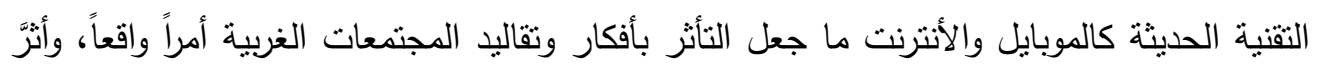

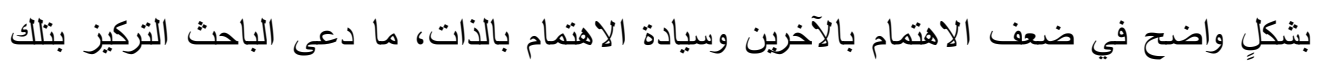

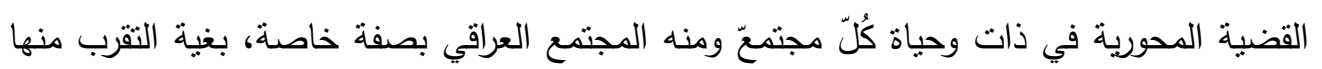

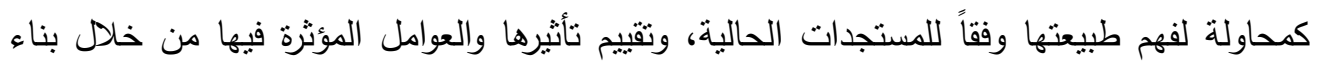

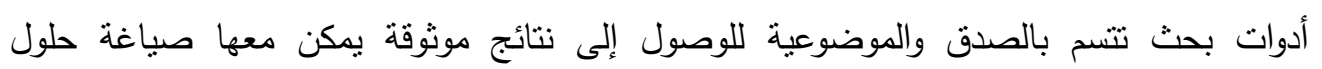


ومعالجات هادفة بنهاية البحث، خصوصاً وإنهُ لم يقع تحت يد الباحث دراسة عراقية أو عربية في

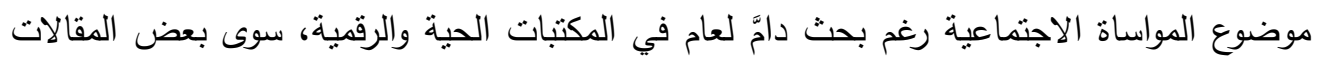

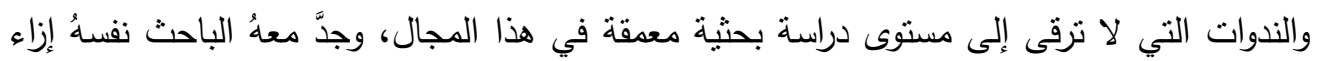

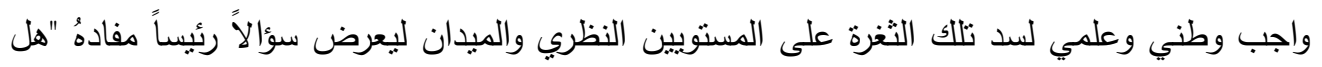

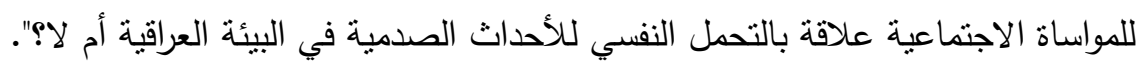




\section{مجلـــة كليـــة التربيـــة}

\section{ثانياً - أهداف البحث \\ يهذف البحث الأتي إلى التعرف:-}

1-فيما إذا كانت هناك علاقة بين المواساة الاجتماعية والتحمل النفسي للأحداث الصدمية.

ץ-فيما إذا كانت هناك علاقة بين المواساة الاجتماعية والتحمل النفسي للأحداث الصدمية على وفق

متغير العمر.

ب-فيما إذا كانت هناك علاقة بين المواساة الاجتماعية والتحمل النفسي للأحداث الصدمية على وفق متغير الجنس.

ع-فيما إذا كانت هناك علاقة بين المواساة الاجتماعية والتحمل النفسي للأحداث الصدمية على وفق متغير المكانة الاجتماعية.

ه-فيما إذا كانت هناك علاقة بين المواساة الاجتماعية والتحمل النفسي للأحداث الصدمية على وفق متغير التحصيل الدراسي. 


\section{مجلـــة كليـــة التربيـــة}

\section{ثالثاً -حدود البحث}

كما تحدد البحث الحالي ب:-

ا-المتغيرات النفسية الاجتماعية كُلٍ من"المواساة الاجتماعية، والتحمل النفسي، والأحداث الصدمية الإرهابية".

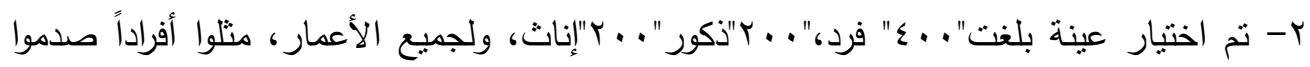

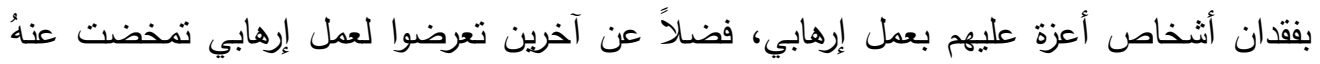

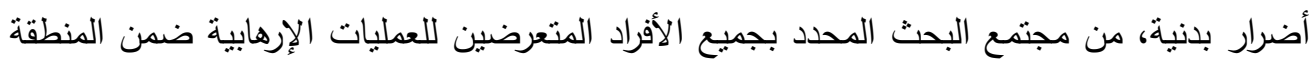

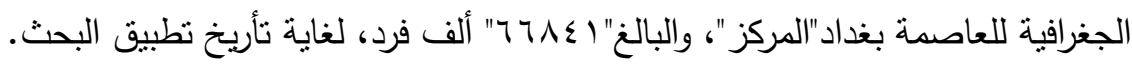

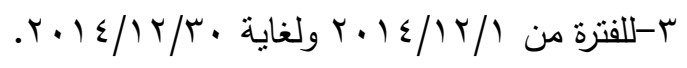


رابعاً - تحدبا المصطلحات

كما تم تعريف المصطلحات الرئيسة في البحث وكما يأتي:-

Social Consolation المواساة الاجتماعية

تم تعريف المواساة الاجتماعية من قبل عدد من العلماء والباحثين في العلوم النفسية والاجتماعية، وفيما يأني بعض منها:-

أ-عرف أوبنهايمر، (... ؟، المواساة الاجتماعية بأنها:-

ذلكَّ السلوك المتمثل بمشاركة الآخرين مشاعرهم صعبة التوافق نفسياً جراء موقف محزن أو محبط،

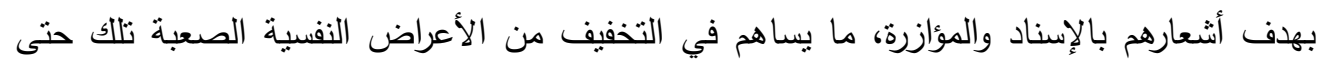

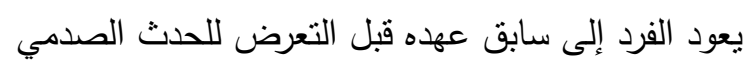

."Obenhimer.2001.P.127"

ب-كما عرفتَّ أبو ليلة 9 ... ب، المواساة الاجتماعية على إنها:-

عملية اجتماعية شائعة لاى الناس في معايثتهم لبعضهم البعض أوقات الأزمة، ما بسهم في

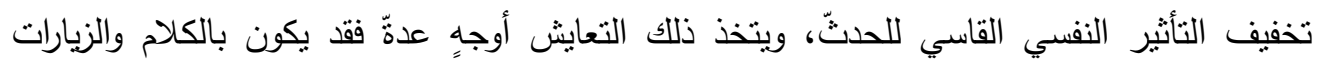

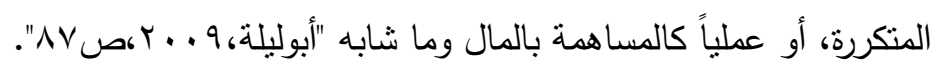




\section{مجلـــة كليـــة التربيـــة}

التعربف النظري

تبنى الباحث تعريف أبو ليلة9 . . بللمواساة الاجتماعية تعريفاً نظرياً للبحث الحالي، إذّ استتد إليه

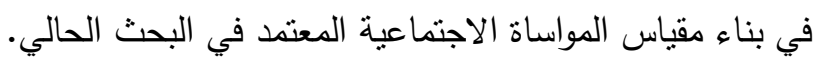

\section{التعريف الإجرائي}

هو الدرجة التي يحصل عليها المستجيب على مقياس المواساة الاجتماعية المعتمد في البحث الحالي.

\section{r-التحمل النفسي Psychological Endurance}

$$
\text { أ-عرف كاتيل } 1979 \text { التحمل النفسي بأنهُ :- }
$$

أحد أبرز سمات الثخصية التي تتضح بقدرة الفرد على تحمل الضغوط والمشكلات التي تواجهه في مجالات الحياة المختلفة عائلية أو دراسية أو مهنية أو اجتماعية...إلخ، وتلك الآلية النفسية تستعملها الذات للتكيف مع المحيط البيئي بما ينضمن من تحديات ومواقف صعبة للمحافظة على استمراريتها في مواصلة النشاط في الحياة"Kattail, 1969,P.40". ب-كما عرف الغريري • ( ب التحمل النفسي على إنهُ :قدرة الفرد على مواجهة الضغوط الناجمة عن مواقف الحياة ومشكلاتها، إذّ ينتاب الفرد

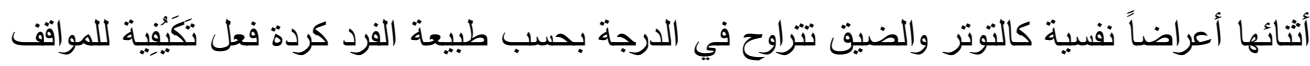

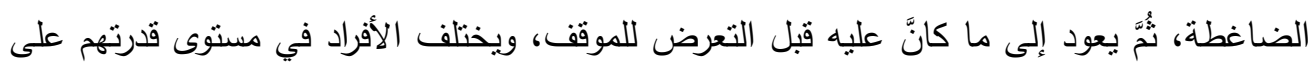

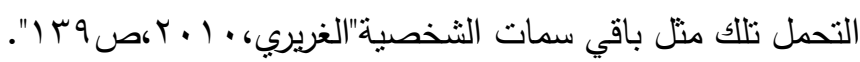


التعريف النظري

وقد تننى الباحث تعريف الغريري، • ( • ك كتعريف نظري للتحمل النفسي، كونه استتد إليه في بناء مقياس التحمل النفسي المعتمد في البحث الحالي.

\section{التعريف الإجرائي}

هو الدرجة التي يحصل عليها المستجيب على مقياس التحمل النفسي الدعتمد في هذا البحث الحالي.

Shock Accidents ب-الأحداث الصدمية

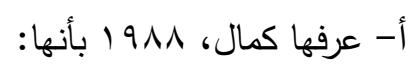

كُلّ حدث أو موقف يخرج عن النمط الاعتيادي يواجهه الفرد في حياته لهُ كفقدان عزيز أو خسارة

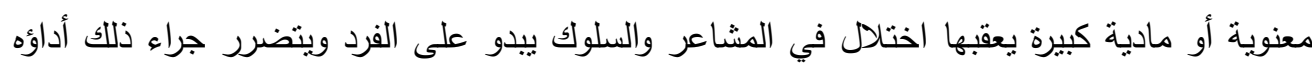

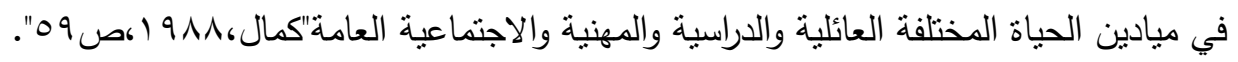

$$
\text { ب-كما عرفها آرون بيك،م. . ب بأنها: }
$$

تلاك الأحداث عالية الثدة أو مختلفة النمط عما يشهده الفرد في حياته اليومية الاعنيادية ويتفاعل معها وتحدث لديه جملة من الأعراض Symptomsالنفسية والعصبية أبرزها القلق والتوتر وقد تغادره

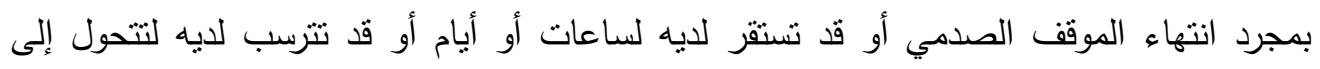

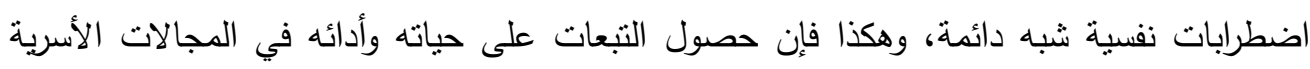

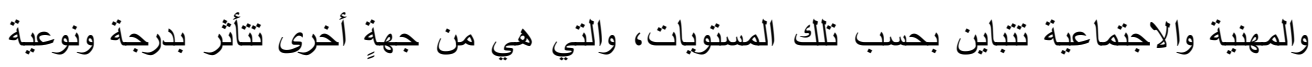

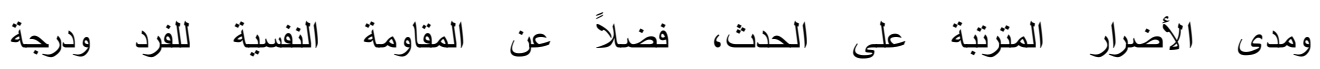
تحمله"Bick,2008,P.96". 


\section{مجلـــة كليـــة الترييــة}

\section{التعريف النظري}

تبنى الباحث تعريف بيك،Bick، ^ . rالمنقام الذكر كتعريف نظري، كونه استمد منه بعض الفقرات التي ضمنها في مقياسي البحث للمواساة الاجتماعية والتحمل النفسي المعتمدين في البحث الحالي.

\section{التعريف الإجرائي}

هو الدرجة التي يحصل عليها المستجيب على مقاييس البحث المتتدة في البحث، والتي تعكس

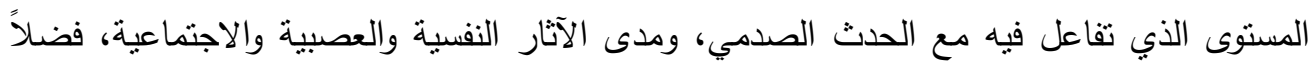
عن التبعات في مجالات الحياة المختلفة. 


\section{الفصل الثاني}

\section{إجراءات البحث}

لتحقيق أهداف البحث المحددة في الفصل الأول، والمتمثلة بقياس متغيري"المواساة الاجتماعية والتحمل النفسي" لمتعرضي الأحداث الصدمية الإرهابية في المجتمع العراقي "العاصمة بغداد مثالاً" والمتغيرات الديموغرافية المرتبطة بهما، قامَّ الباحث ببناء مقياس لكلٍ منهما، فضلاً عن اعتماد المنهج الارتباطي.

\section{ا مجتمع وعنية البحث}

تنَّ اختيار عينة بلغت" . . ع"فرد،" . . ץ" ذكور" . . ب"إناث، ولجميع الأعمار ، مثلوا أفراداً تعرضوا لأحداث صدمية حُدِدَتّ بفقدان أشخاص أعزة عليهم كأخ أبن أو أب أو أم أو صديق مقرب في العمليات الإرهابية، فضلاً عن الأشخاص الذين صادف نواجدهم في مكان حدوث العمليات الإرهابية وتعرضوا للصدمة بأنفسهم ونجوا بجروح بدنية جراء ذللك، بعد إحصاءهم من السجل العام لضحايا

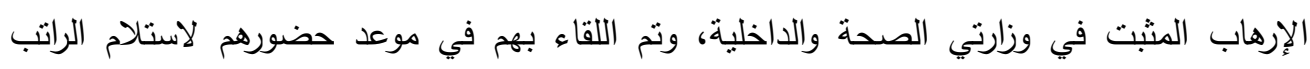
المخصص لضحايا الإرهاب، وآخرين تتطبق عليهم مواصفات البحث تم تأمين الاتصال بهم ومقابلتهم في محل سكناهم، من مجتمع البحث الذي يمثل الأفراد المتعرضين للصدمات الإرهابية ضمن

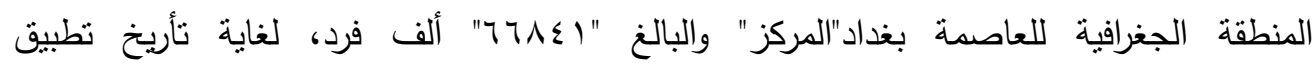

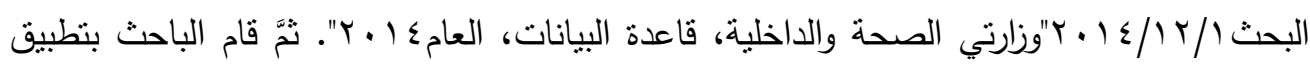
مقاييس البحث عليهم بطريقة المقابلة، وقد توخى الباحث تحقيق جملة أمور واجب إتباعها بإشارة مراجع القياس النفسي تمثلت ب: تحفيز المستجبيين على إعطاء الاستجابة الصادقة، الاستفسار عن بعض المعلومات الخاصة بالمستوى المعاشي، والتحصيل الدراسي، وتخمين المكانة الاجتماعية من عدة مؤشرات أبرزها المستوى الاقتصادي وطريقة الكلام ومنطقة السكن والثقافة العامة، فضلاً عن بن الوقت المخصص للاختبار ، والذي حُدِدَّ بنصف ساعة كحد أعلى لكل مستجيب. 


\section{مجلـــة كليـــة التربيـــة}

r. أداتا البحث

$$
\text { أ- - جمع الفقرات وصياغتها }
$$

لبناء مقياسي المواساة الاجتماعية والتحمل النفسي، كان الباحث قدّ إثنَّقَّ الفقرات لمقياس المواساة

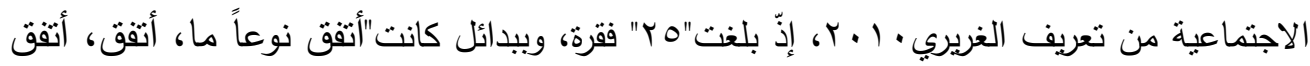

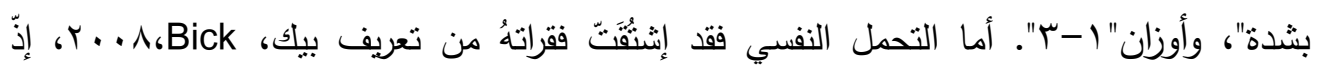

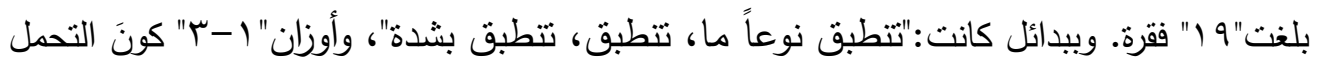
النفسي يتألف من مستويات"ضعيف، متوسط، عال" بحسب إنثارة بيكى .. . . . وذلك تمهيداً لنقديمها

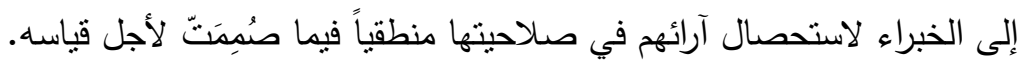

ب- صدق المقياسين

يُعَّ صدق المقياس من الخصائص اللازمة في بناء الاختبارات والمقاييس، وهو من الخصائص

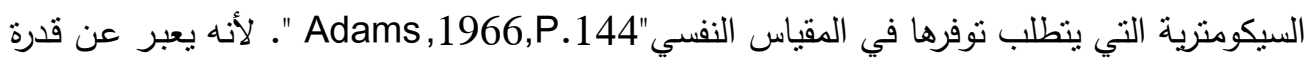

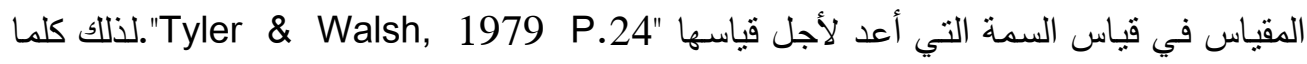
تعددت الأدلة أو المؤشرات على صدق المقياس زادت الثقة باستخدامه" وعليه فقد تحقق الباحث من صدق المقاييس من خلال المؤشرات الآتية:

$$
\text { أولاً - - الصدق الظاهري }
$$

كثيراً ما بستخدم الصدق الظاهري مؤشراً لصدق مقاييس الثخصية، ذلك من الصعب استخدام

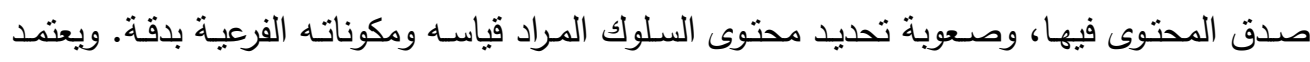

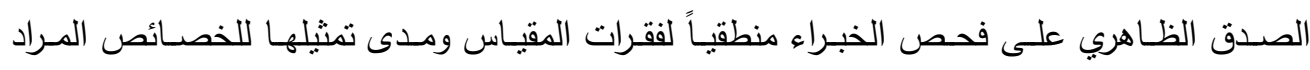
قياسها"Anderson,1965,P.16". 


\section{مجلـــة كليــة التربيــة}

وقدّ نمّ عرض الفقرات الـ "ه ب" لمقياس المواساة الاجتماعية، ويمثل ذلك المقياس بصورته الأولية

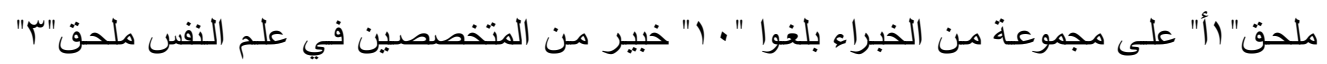

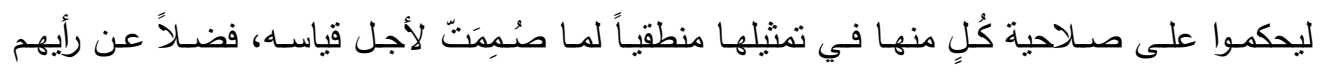

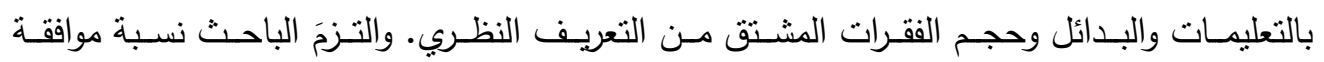

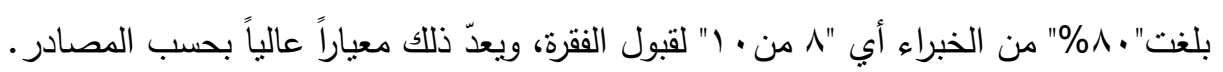
وقد أجمع الخبراء على إبقاء جميع الفقرات، سوى بعض التعديلات في الصباغة نمَّ الأخذ بها، ليكون المقياس بفقراته الـ "هـ" فقرة ملدق"بأ" بصيغته النهائية جاهزاً للتطبيق.

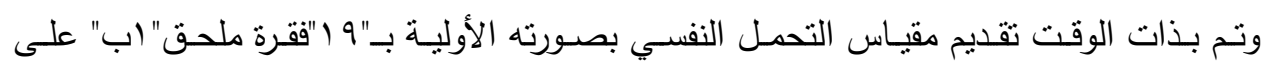

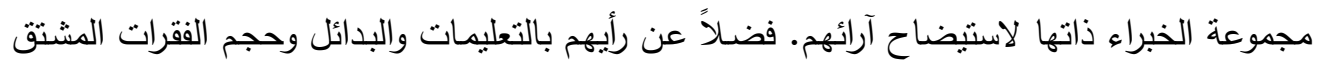

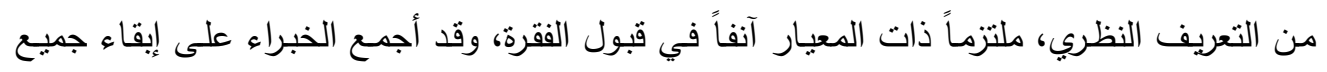

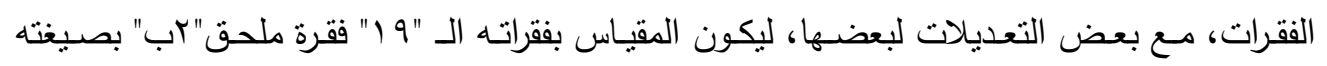

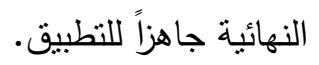
ثانياً - تحليل الفقرة:

يُحّد إجراء تحليل الفقرة الأساس في بناء الاختبار من دليل الفقرات المجموعة، والتي اختيرت

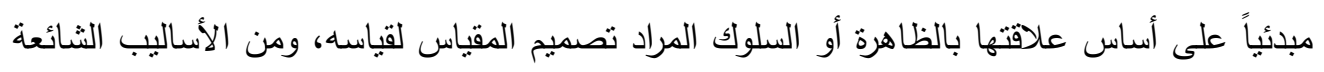
في هذا الإجراء هو أسلوب التمييز باستخدام العينتين المنطرفتنين

."Anastasia, 1988, P.210-213"

1-التمييز:

ويعني قابلية الفقرة على إظهار الفروقات بدقة فيما بين الأفراد المختبرين في السلوك المصمم

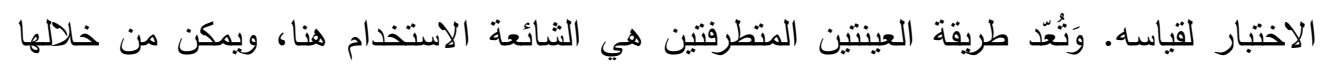
التعرف على قابلية الفقرة في المباينة بين مجموعات محكيةزمجموعة المحك الأعلى والأدنى المختارة من المنطرفات في التوزيع، والتطرف الأكبر سبتضمن التمايز "Discrimination"، وفي التوزيع 
(التاسع عشــر

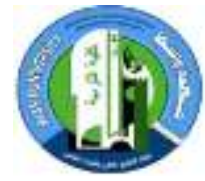

\section{مجلــــة كليــــة التربيــــة}

الطبيعي فإن نقطة التسلسل الموازنة بين الثرطين التي تصل بين الأعلى والأوطأ هي الـ"Yr" "Winters, 1996,P.4". وباستخدام الاختبار التائي لعينتين مستقلتين "t-test" لمعرفة دلالة الفروق بين المجموعتين العليا والدنيا لدرجات كل فقرة من فقرات المقياس، فإن جميع الفقرات في مقياسي المواساة الاجتماعية والتحمل النفسي على وفق متغير الجنس عدّت ذات دلالة إحصائية عند مستوى

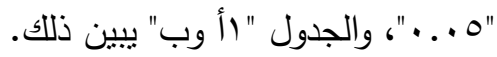

ملحق رقم" ا" : مقياسي المواساة الاجتماعية والتحمل النفسي بصيغتهما الأولية ملحق رقم"ץ" : مقياس المواساة الاجتماعية والتحمل النفسي بصيغتهما النهائية ملحق رقم"ب" : قائمة الخبراء.

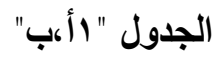

قيم"ت" لعينتين مستقلتين لمتعرضي الأحداث

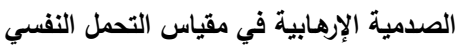

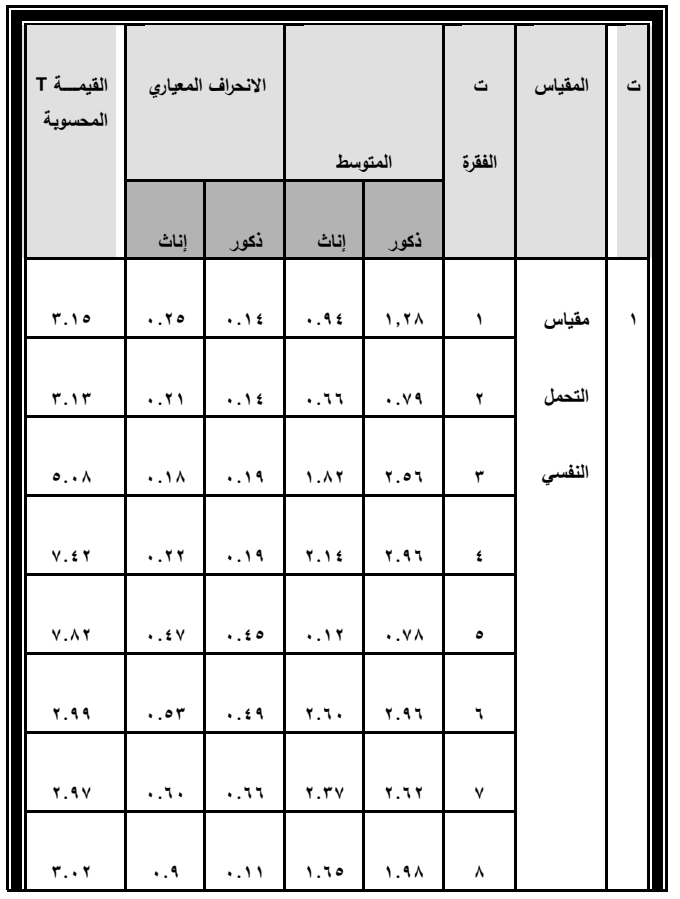

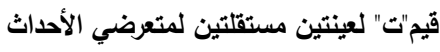

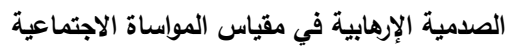

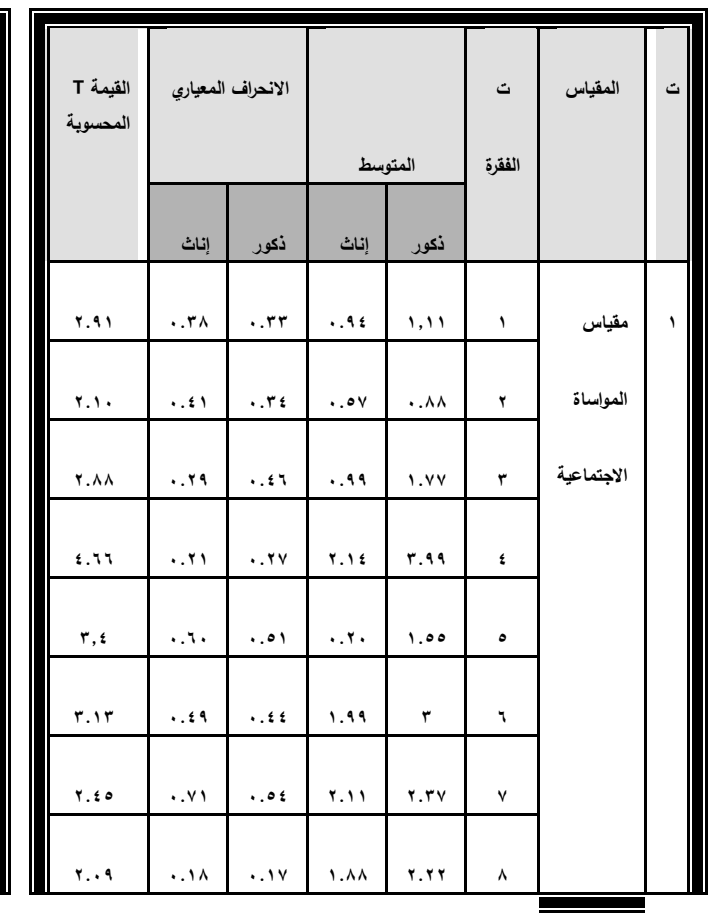

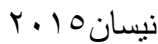




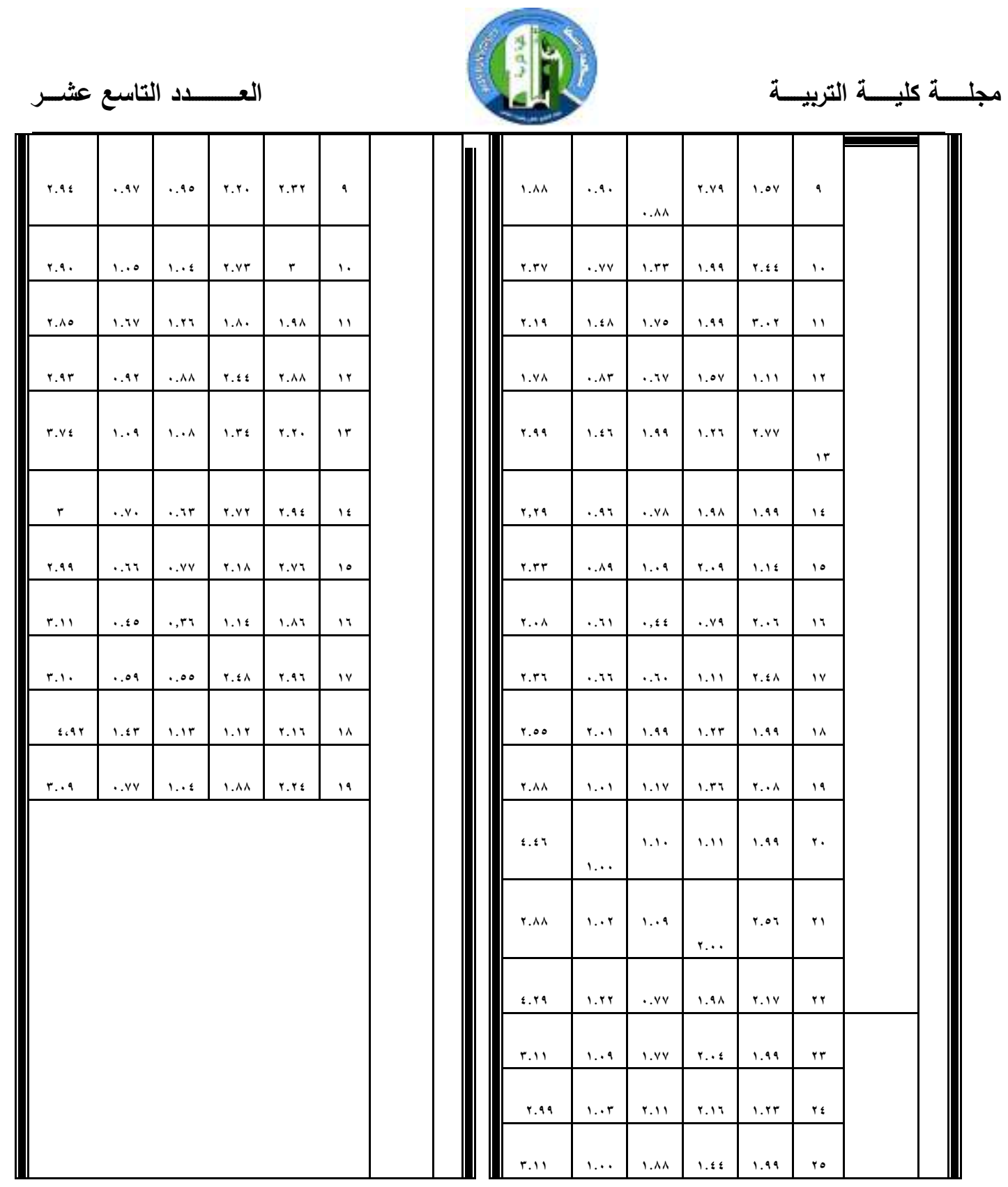

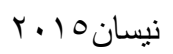




\section{مجلـــة كليـــة التربيـــة}

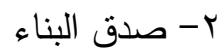

يستخدم صدق البناء بكثرة في المقاييس الثخصية ويعتمد على افتراضات نظرية يتم التحقق منها

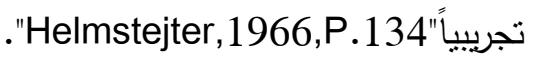

ويسمى أحيانا بصدق الدفهوم أو صدق التكوين الفرضي، ويدل على مدى تمثنل المقياس لتكوين

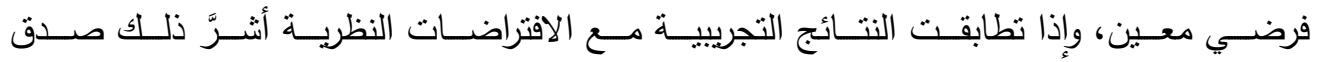
المقياس"Allen\& yen,1979,P.108".

ويمكن الاستدلال على مؤشرات صدق البناء من خلال ارتباط كل فقرة بالدرجة الكلية للمقياس،

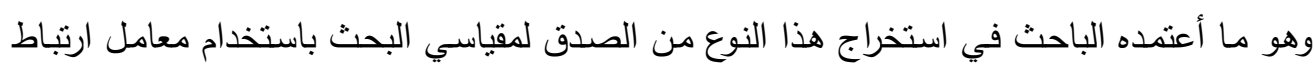

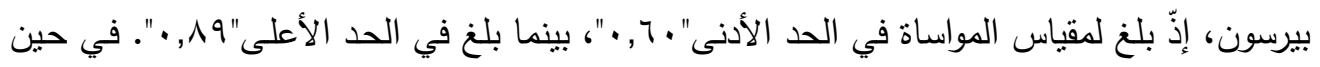

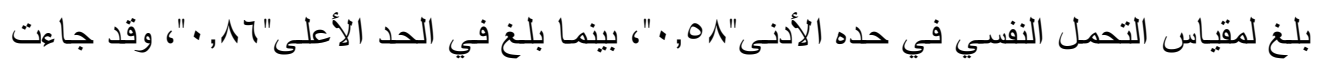

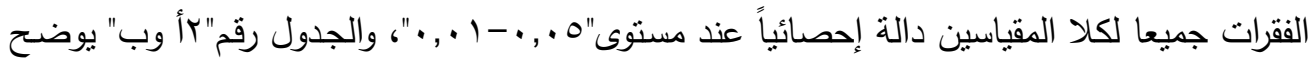
ذلك. 


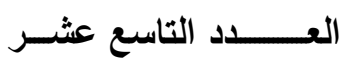

\section{مجلـــة كليــة التريبــة}

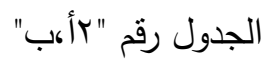

معاملات ارتباط كل فقرة بالدرجة الكلية

لمقياس التحمل النفسي
معاملات ارتباط كل فقرة بالدرجة الكلية

لمقياس المواساة الاجتماعية
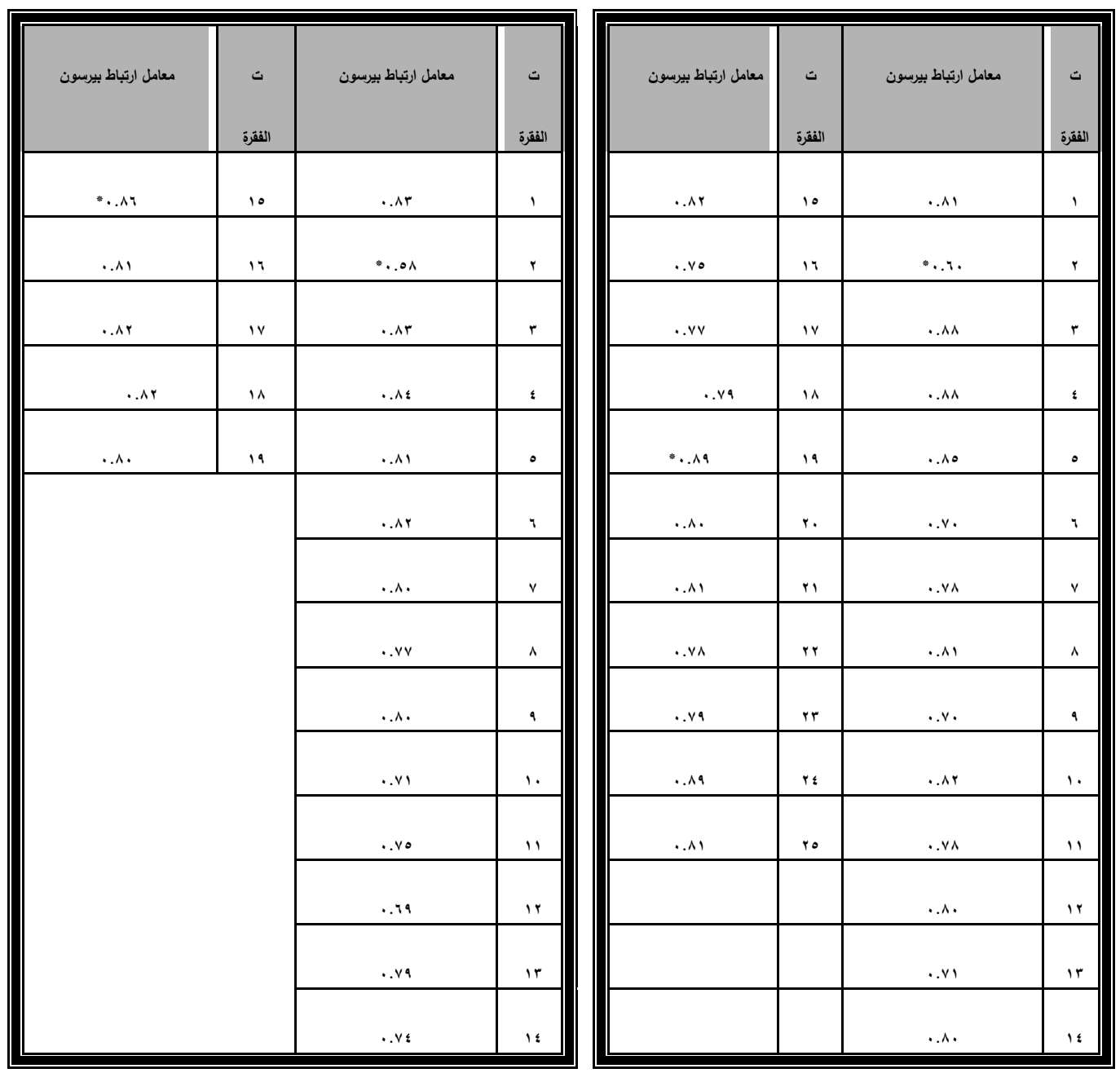

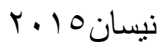




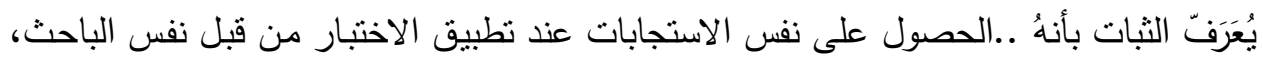

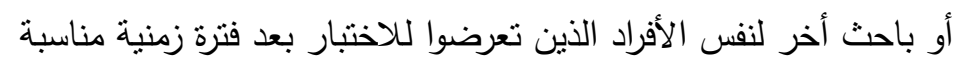
."Winters, 1996, P.13"

وقد استخرج الباحث الثبات بطريقتين هما:

$$
\text { أولاًا- إعادة الاختبار }
$$

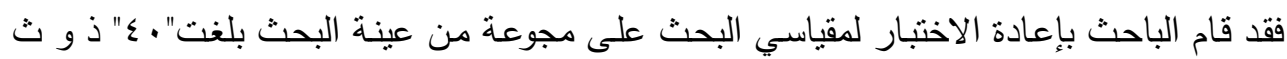

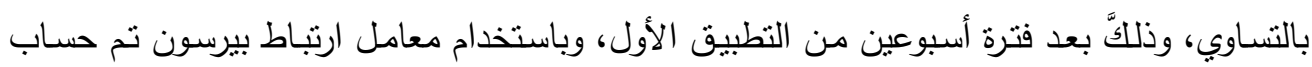

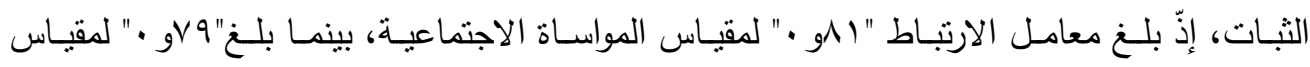

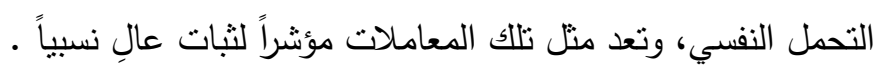
ثانياً - معامل ألفا كرونباخ

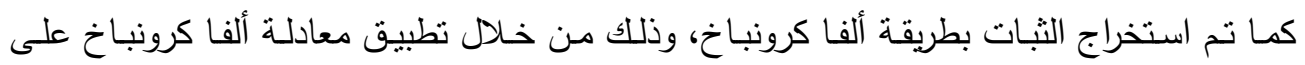

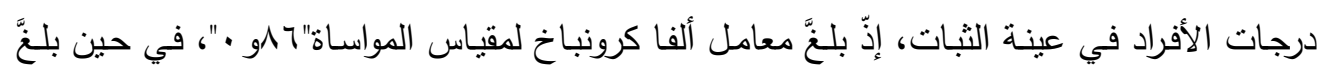

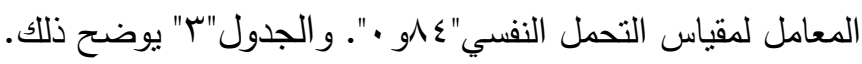




\section{مجلـــة كليـــة التربيـــة}

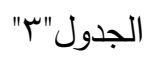

معامل ثبات مقياسي المواساة الاجتماعية والتحمل النفسي بطريقتي إعادة الاختبار ومعامل

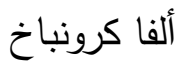

\begin{tabular}{|c|c|c|c|}
\hline معامل ألفا كرونباخ & طريقة إعادة الاختبار & الاختبار & ت \\
\hline$\cdot, \wedge 7$ & $\cdot, \wedge)$ & المواساة الاجتماعية & .1 \\
\hline$\cdot, \wedge \varepsilon$ & $\cdot, \vee \vee q$ & التحمل النفسي &.$r$ \\
\hline
\end{tabular}

د. النطبيق النهائي

بعد أن أكهل الباحث تحقيـق الخصـائص السيكومترية لأدوات البحث كُلٍ من مقياس المواسـاة

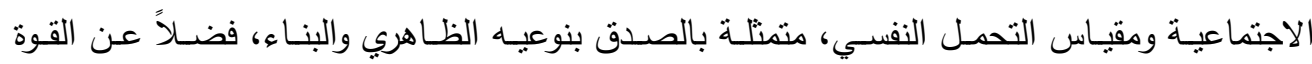

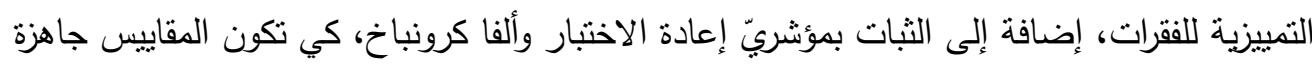
للتطبيق على عينة البحث.

\section{r. الوسائل الإحصائية}

استعمل الباحث في تحقيق مطالب بحثه الوسائل الإحصائية الآتية:

أ. النسبة المئوية لاستخراج عامل الإتفاق بين الخبراء"الصدق الضاهري". ب. الاختبار التائي لعينتين مستقلتين لإستخراج القوة التمييزية لمقياسي البحث.

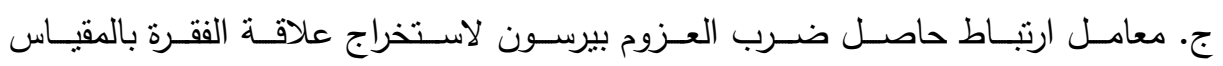
لمقياسي البحث"صدق البناء". ولاستخراج الثبات بطريقة إعادة الاختبار . د. معامل ألفا كرونباخ لاستخراج الثبات لمقياسي البحث.

\section{نيسان 10 r.}




\section{عرض النتائج ومناقشتها}

لتحقيق أهداف البحث التي حُدِدَت في الفصل الأول منه قام الباحث بمايأتي :-

1- التعرف فيما إذا كانت هناك علاقة بين المواساة الاجتماعية والتحمل النفسي للأحداث الصدمية الإرهابية.

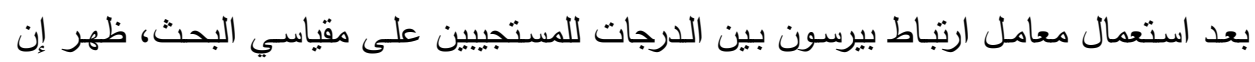

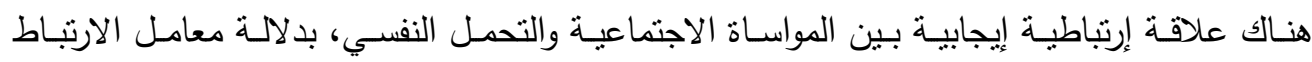

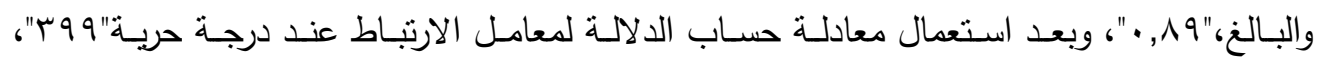

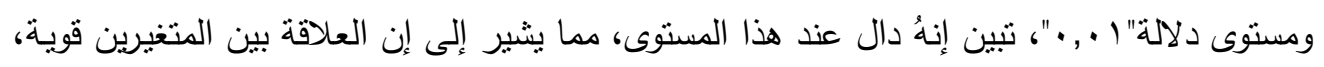

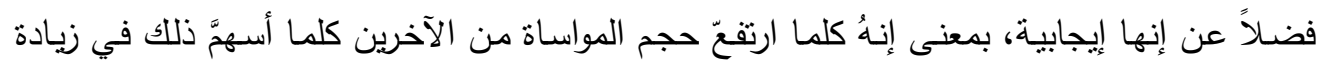

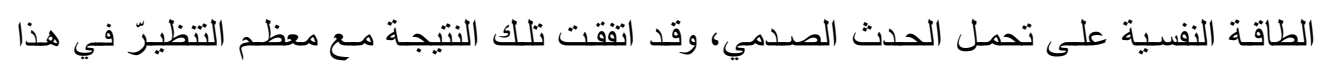
السياق"Faiber,1978,P.124".

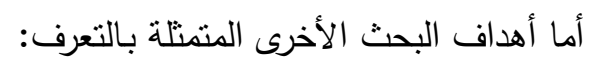
ا - فيما إذا كانت هناك علاقة بين المواساة الاجتماعية والتحمل النفسي للأحداث الصدمية على وفق متغير العمر.

ب-فيما إذا كانت هناك علاقة بين المواساة الاجتماعية والتحمل النفسي للأحداث الصدمية على وفق متغير الجنس.

ب-فيما إذا كانت هناك علاقة بين المواساة الاجتماعية والتحمل النفسي للأحداث الصدمية على وفق متغير المكانة الاجتماعية. 


\section{مجلـــة كليـــة التربيـــة}

ع-فيما إذا كانت هناك علاقة بين المواساة الاجتماعية والتحمل النفسي للأحداث الصدمية على وفق متغير التحصيل الدراسي.

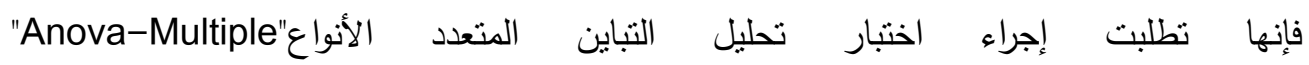
"Winer,1962,P.176" لمعرفة طبيعة تفاعل متغيرات البحث الرئيسة كُلٍ من المواساة الاجتماعية

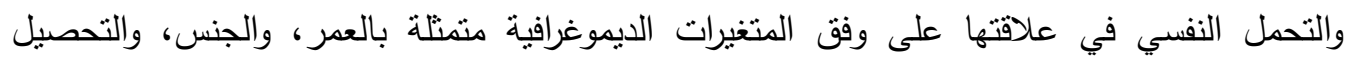

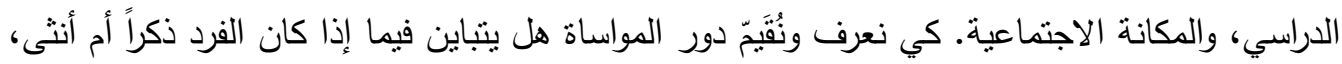

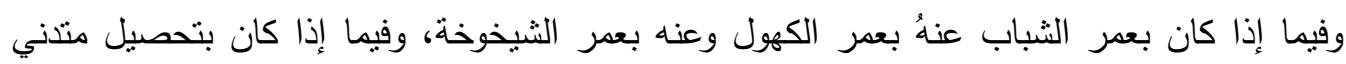

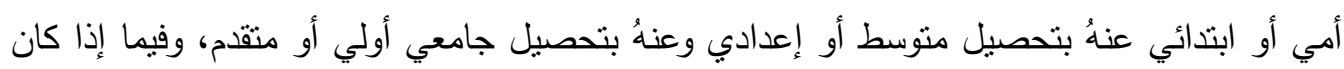

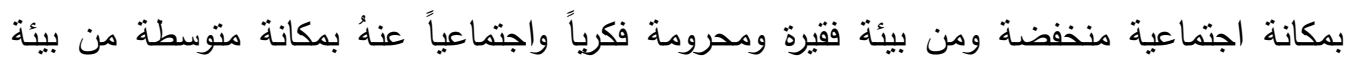

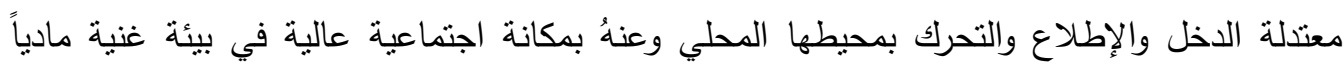
وبمحل سكن واسع متضمن لإمكانيات عالية في وسائل الاتصال والاطلاع والسفر والعيش.

وكذلك بالنسبة للتحمل النفسي هل يتباين في درجته ومداه بين الذكور والإناث، وبين الثباب

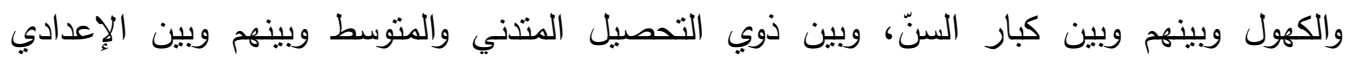

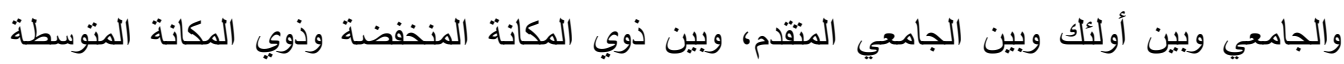

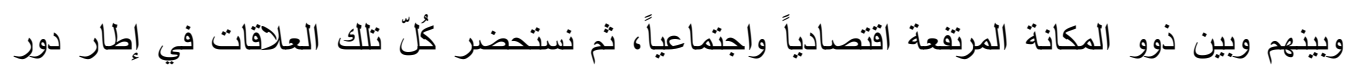

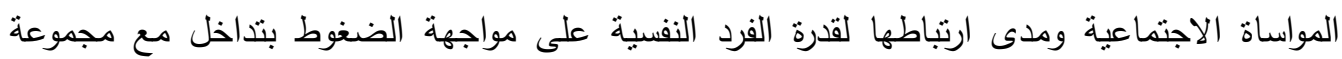
العوامل والمتغيرات مثقدمة الذكر .إنها شبكة من العلاقات تتيح لنا معرفة تفصيلية عما تلعبه المواساة الاجتماعية عبر خطوط اجتماعية مختلفة وطبيعة التحمل النفسي بين أفراد المتنمع المختلفة تضعنا إزاء صورة أوضح وأعمق لتلك القضايا النفسية والاجتماعية الإستراتيجية.

فبالنسبة للتفاعل على وفق العمر أثنارَ اختبار الفروق بطريقة شيفيه بأنَّ هناك فرقاً دالاً إحصائياً عند

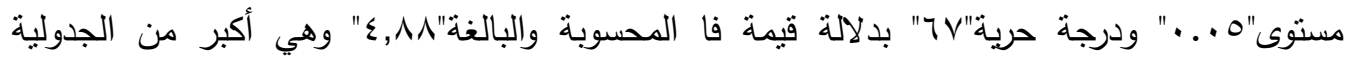

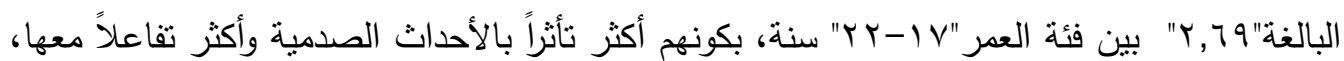

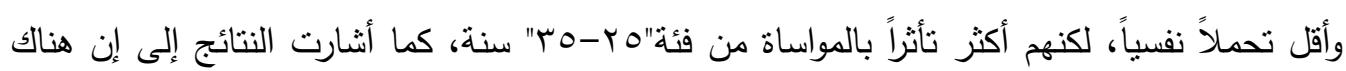

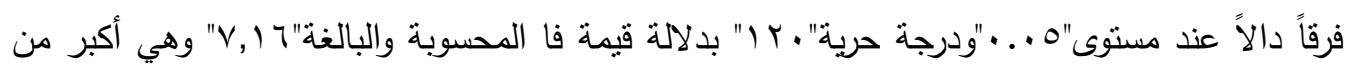




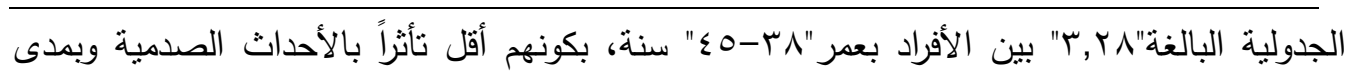

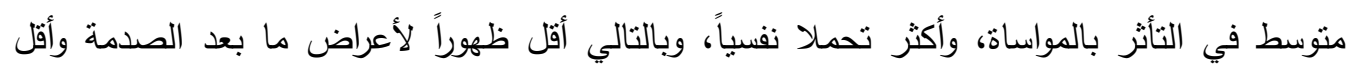

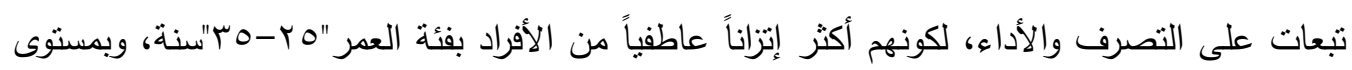
دلالة أكبر من الفئة"V ا-YY" سنة بلغ" ا...." بقيمة فا البالغة"Vr,q" وهي أكبر من الجدولية

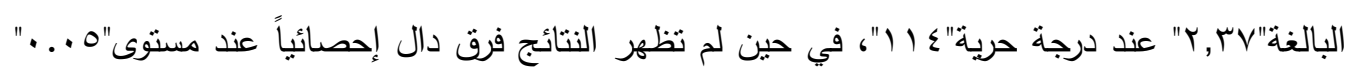

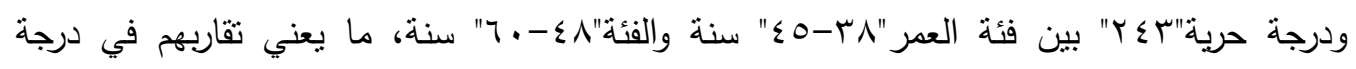

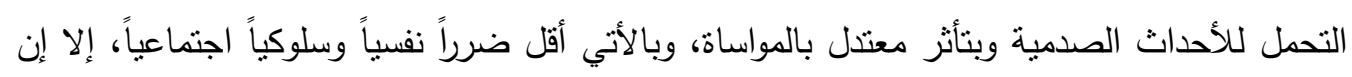

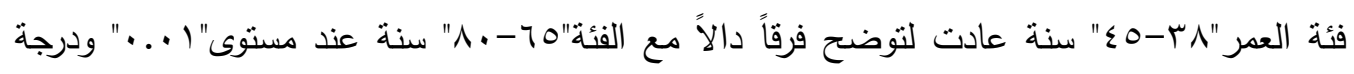

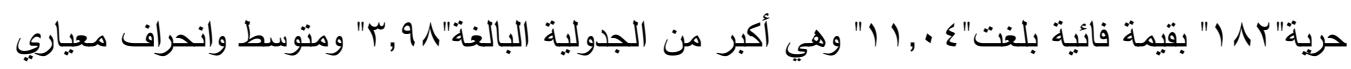

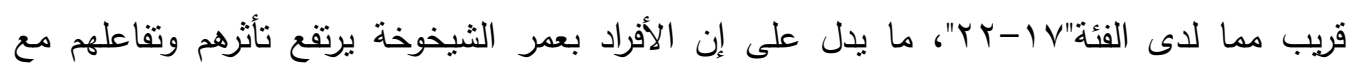

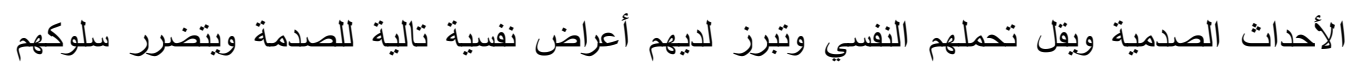
ومشاعرهم بشكل ملفت ما يجعلهم مصداقاً لقوله عز من قال"اله الذي خلقكم من ضعف ثخ من بعد ضعفٍ قوة ثم من بعدِ قوةٍ ضعفاً وشيبة"، وهو ما تتبتهُ تلك النتائج وغيرها من البحوث للقدرات النفسية،

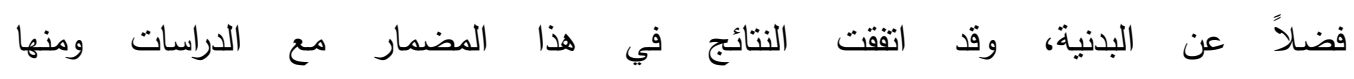

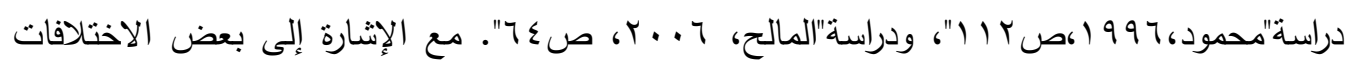

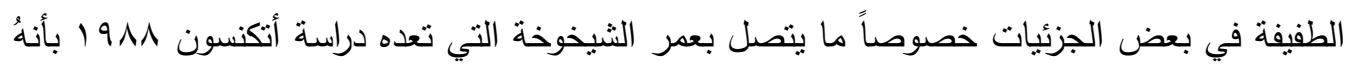

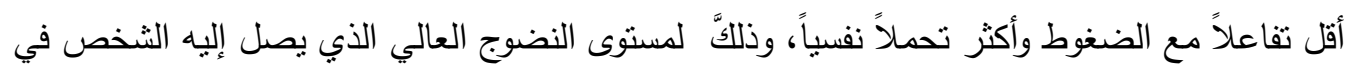

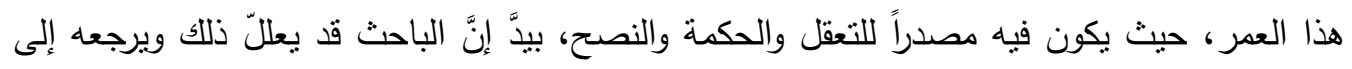
الاختلافات الثقافية بين مجتمعاتتا وبين المجتمعات الغربية التي هي بالأساس وهذا بالضرورة يشمل المسنين بأنهم أكثز مادية وأقلُ تعاطفاً عن نظرائهم في مجتمعنا العربي عموماً ومنهُ العراقي بوجهٍ خاص ذللك بسبب الطبيعة الثقافية والعقائدية التي تجعلهم أكثر تفاعلاً مع الأحداث وبعاطفية عالية"Atkinson, 1988,P.147". 


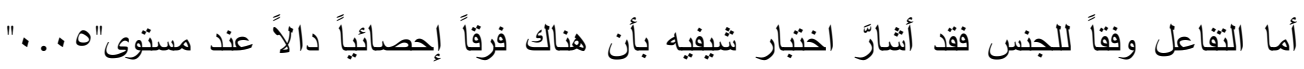

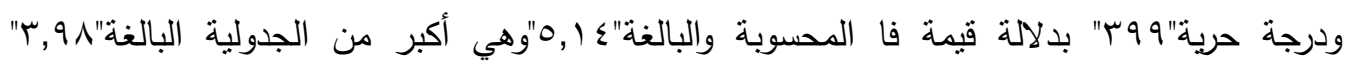

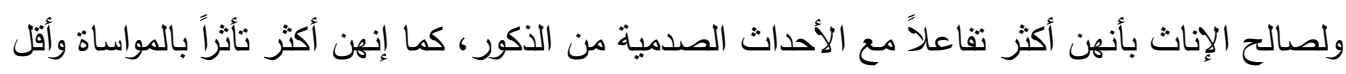

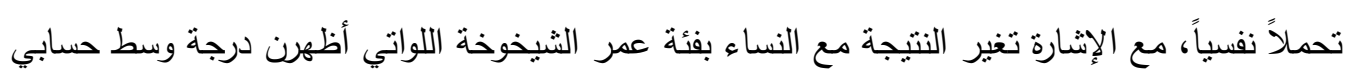

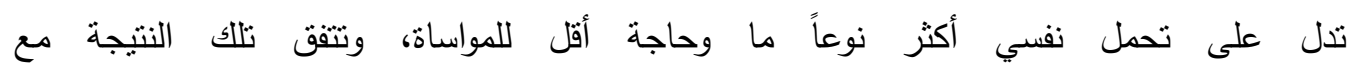
دراسة"Stewart,1992"، وعموماً يعرض النتظير تفسيراً للنتيجة هنا بأن النساء أكثر عاطفية من وناء

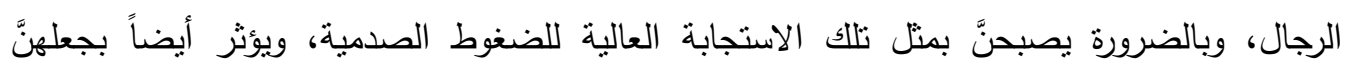

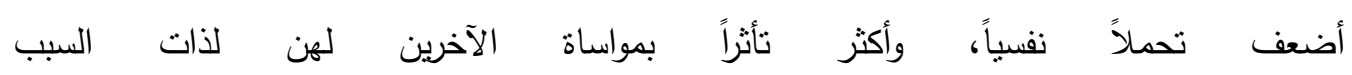
"Douclas\&Others, 2005,P.80"

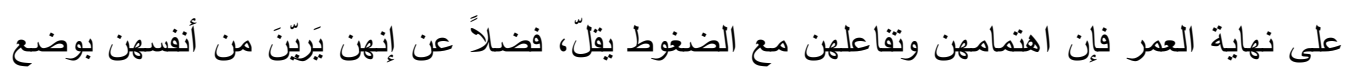

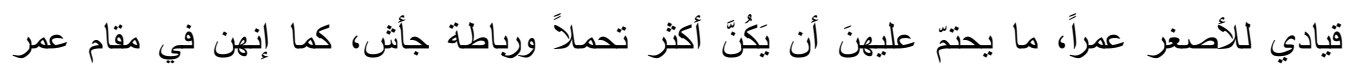
يفرض تقديم المواساة ولا يتطلبها. ولكن من ناحية أخرى قد يرتفع ذلك التحمل لاى النساء بفئة التحصيل

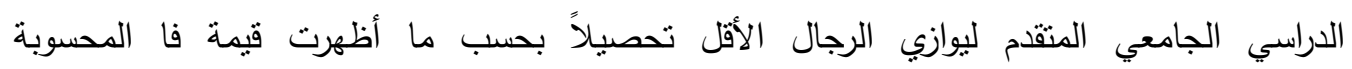

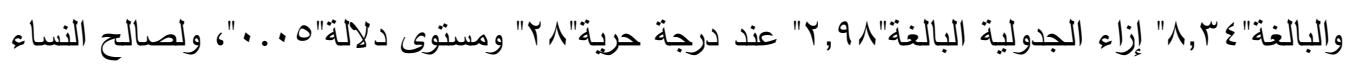

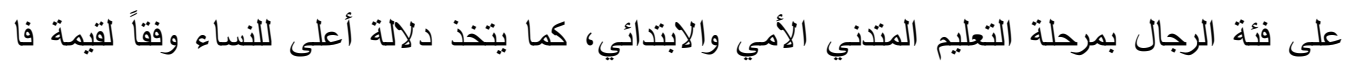

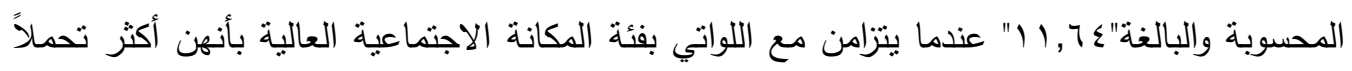

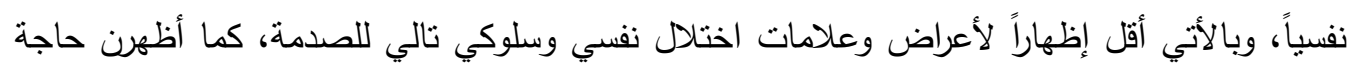

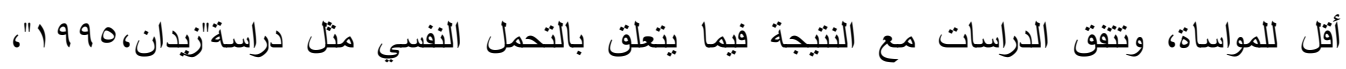

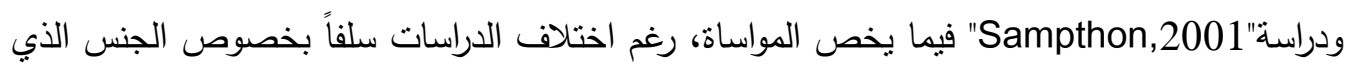

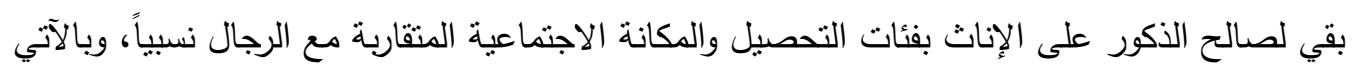

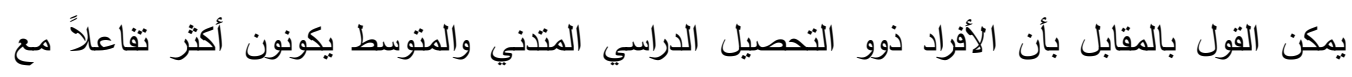

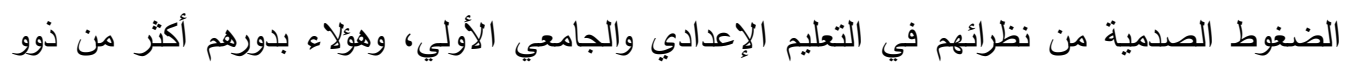

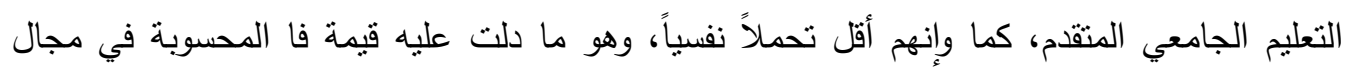

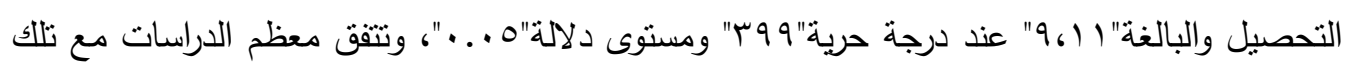
النتيجة ومنها دراسة"Cobye,1987"، ودراسة"كوهين وآخر 910 ا"، وتبرر ذللك بأنه كلما ارتفع سُّلَّم التحصيل كلما أسهم ذلك في إنماء بنية معرفية من الإدراك والتفكير الإيجابيين في النظر إلى الحياة 
بكونها ميدان للصراع، وإن وقوع الأحداث أمرٌ لامناص منه، وإن الحياة ماضية ولا تتوقف عند حدثٍ

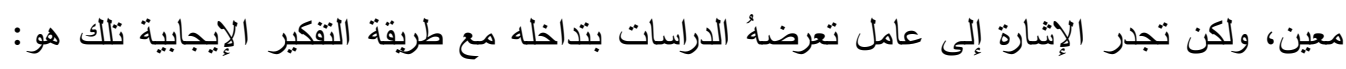

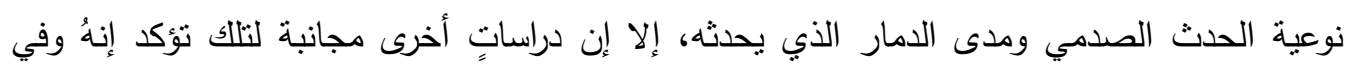
جميع الأحوال تبقى تلك الفئة ذات التحصيل العالي تتفوق في طاقتها بالتحمل على باقي الفئ الفئات التهات خصوصاً على الفئة ذات التحصيل المندني "Alies,2007,P.130".

ب ب الاستنتاجات

بسنتتج في ضوء النتائج المتقدمة ما يأتي :

ا. إن للمواساة الاجنماعية دوراً فاعلاً في التخفيف من الآثار النفسية التابعة للأحداث الصدمية عموماً ومنها الإرهابية كونها السائدة في البيئة العراقية الآن.

r. كذلك بستتتج بأن عامل التحمل النفسي مهم في تحمل الصدمة من جهة، وتأني المواساة لترفع من درجة التحمل النفسي لدى الفرد المتعرض للصدمة.

r. كما بستتتج بأن المواسـاة الاجتماعيـة نتشت الحاجـة لها مـع الأثخاص ذوي مستوى تحمل نفسي ضعيف.

ع. ويستتنج إن الفرد بعمر المراهقة يتفاعل مع الضغوط والحوادث الصدمية ويحتاج المواساة بشكل ملحوظ ويتأثر بها خصوصاً من مجموعة الأقران كونهُ في طور نمو عاطفي ولم يصل للإنتان الانفعالي

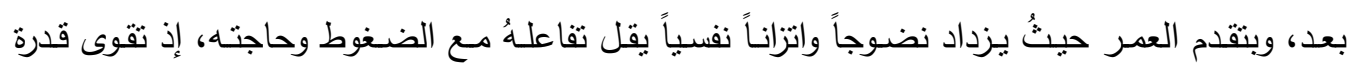
التحمل لديه.

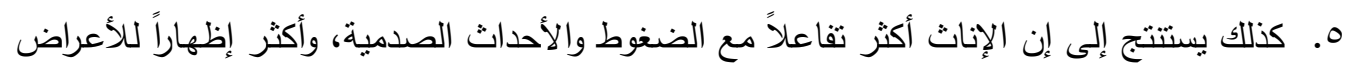

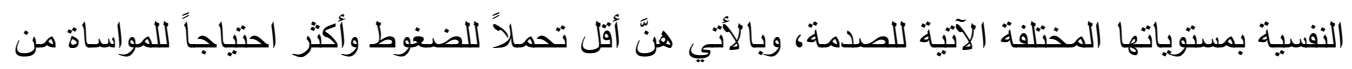




\section{مجــــة كليــة التريبـة}

1. ويستتج أيضاً إلى إنهُ كلما تقدم الفرد في التحصيل الدراسي كلما أثر ذلك على طريقته في التقكير

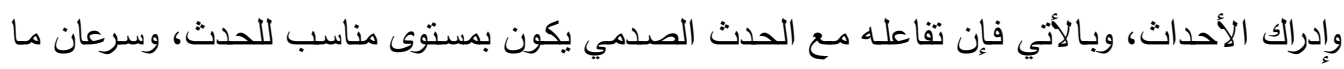

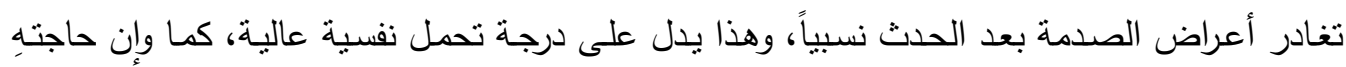

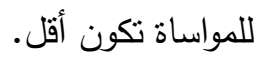

V. . ويستتج أيضاً إلى إن الفرد كلما كان بييئة اجتماعية ضعيفة يعمها الفقر والحرمان والتخلف كلما

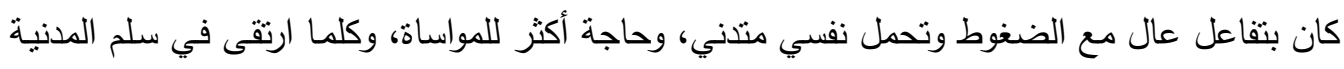

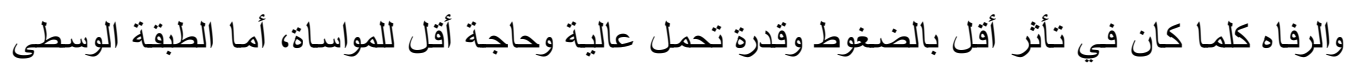
فهي في الوسط هنا أيضاً.

ج. التوصبات كما بوصي الباحث بما يأتي:

ا ـ وزارة الصـحة بضـرورة إجـراء مسـح اجتمـاعي يشــل جميـع محافظـات العـراق يحصـي أعـداد

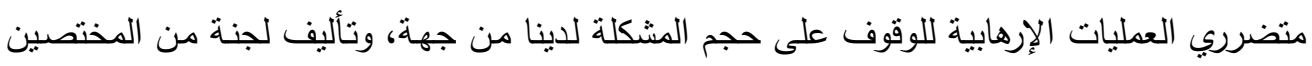

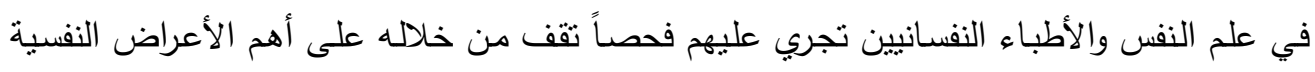

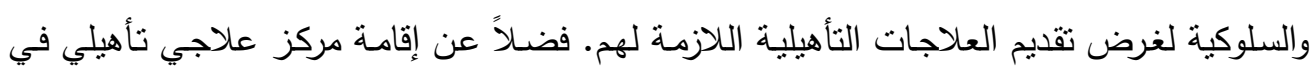

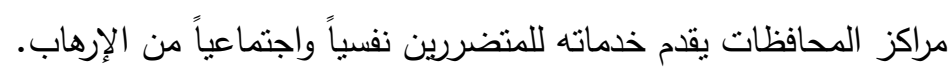

r.وزارة التعليم العالي إقامة مؤتمر دولي تعرض فيه بحوث مثقدمة حول الآثار النفسية والاجتماعية

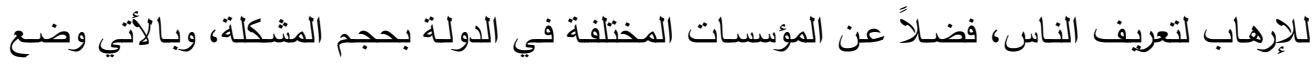

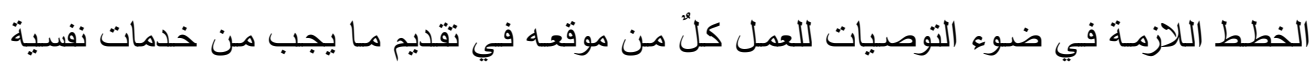
واجتماعية وقانونية لتنلك الثريحة التي لم تعد بالقليلة لا في العدد ولا الأهمية.

rا.جامعة واسط إقامة مؤتمر يدعى فيه الباحثّن من جامعات البلد كافة ليكون ممهداً لمؤتمر التعليم

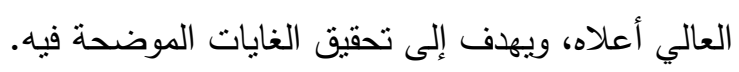


ء .وزارة العمل والثؤون الاجتماعية تأليف فرق عمل في بغداد والمحافظات تأخذ على عاتقها إجراء

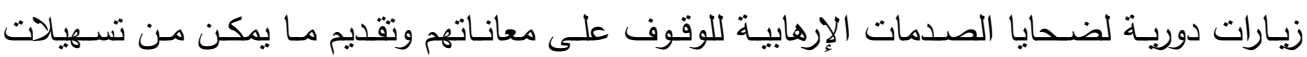

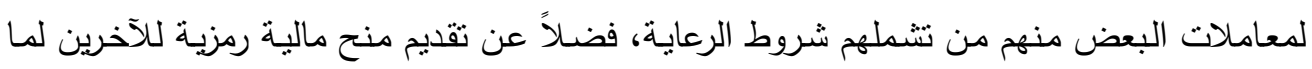

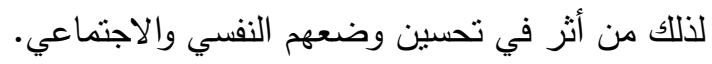

1-وزارة الإعلام إقامة برامج يستضاف بها متخصصين في علم النفس وعلم الاجتماع تلقي الضوء

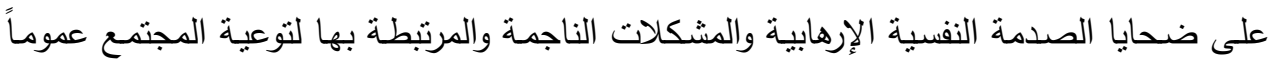

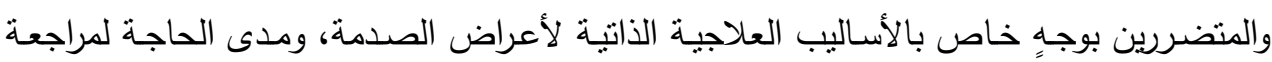
العيادات والمستشفيات التخصصية بهذه الأعراض.

د. المقترحات

يقترح الباحث في ضوء بحثه ما يأني:

ا ـ دراسة متغيرات نفسية واجتماعية عدة في علاقتها بمتغير المواساة الاجتماعية مثل: قلق المستقبل، ضعف الإثارة الحسية ، نمط الثخصية الإحتفاظية، سمة الوطنية.

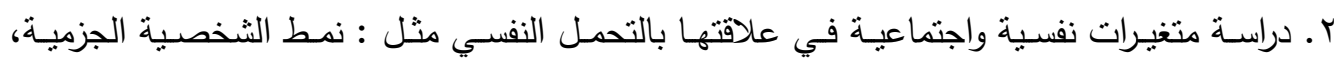
الأسلوب المعرفي"التجنب ـ المغامرة"، مركز السيطرة الخارجي والداخلي.

r-دراسة عدد من المتغيرات الديموغرافية في علاقاتها بمتغيرات البحث : المواساة الاجتماعية

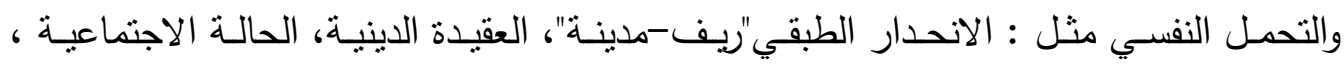

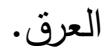




\section{المصادر}

ا. (القرآن الكريم

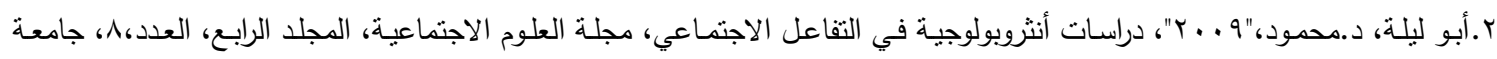

عين شمس، مصر.

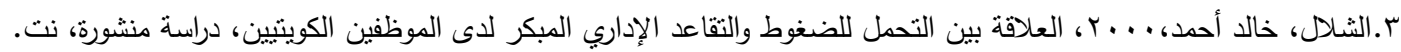

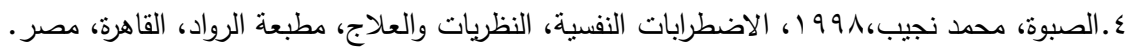

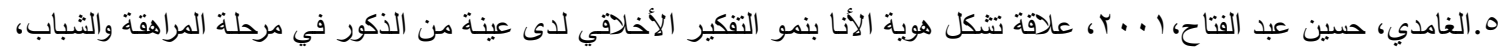

$$
\text { المجلة المصرية للاراسات النفسية، العدد } 9 \text { ب. }
$$

7.المشهداني، أكرم عبد الرزاق " ا. . ץ" : واقع واتجاهات الجريمة في المجتمع العربي "دراسـة تحليأتية اجتماعية"، أطروحة دكتوراه غير

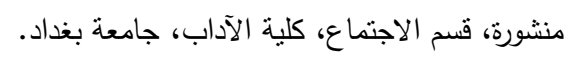

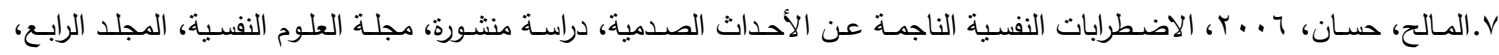

$$
\text { العدد آ جامعة صنعاء، اليمن. }
$$

^.النعيمي، احمد طه، "ץ . . "ا، محددات الرضا الوظيفي للعاملين في المنظمات الحكومية، وزارة الثقافة والإعلام، بغداد.

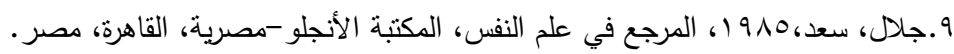

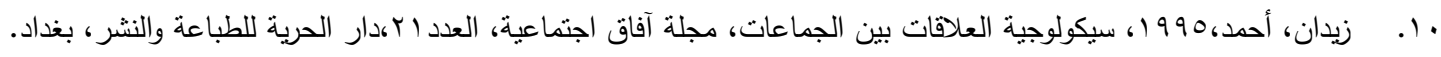

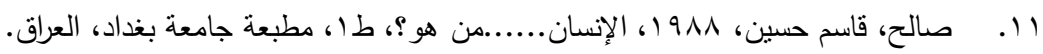

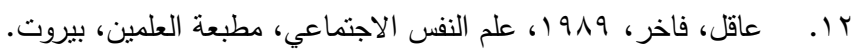

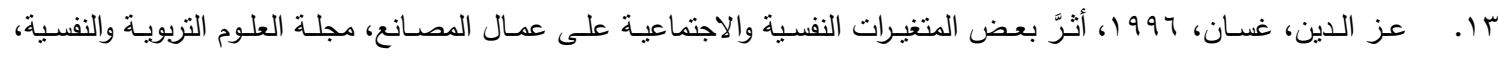

العدد بr، جامعة دمشق، سوريا.

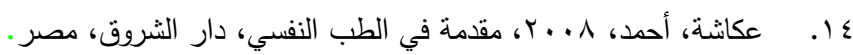

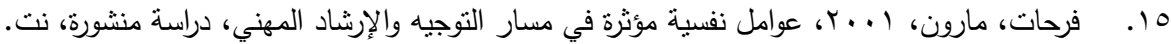

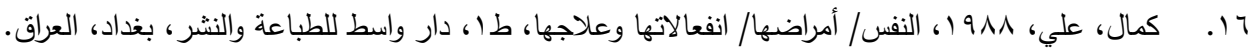

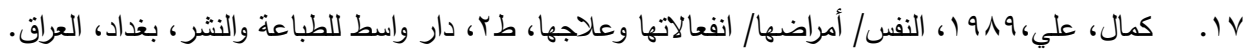

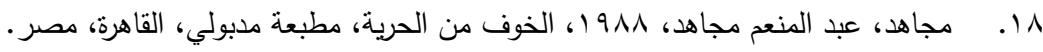

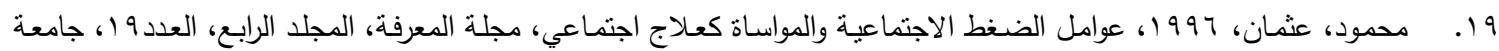

$$
\text { طرابلس، ليييا. }
$$

20. Adams, Georgia "1966" Measurement and Evaluation Education and Guidance . New York .

21. Allen M.J \& Yen .W.N, "1979" , Introduction to Measurement Theory California : Brooklyn .

22. Anderson J.E "1965" The effect of the item Analysis upon the Discriminative Power of an Examination, Journal of Applied Psychological .Vol.19.

23. Anastasia, A. "1988". Psychological Testing "6ed.". Macmillan Publishing Company, New York.

24. Atkinson, S,"1988", The Social Identification" Who is I My Self", Remington Press, London.

25. Bick, A. "2008" . A comprehensive guide book of addiction, Oxford University Press, New York. 

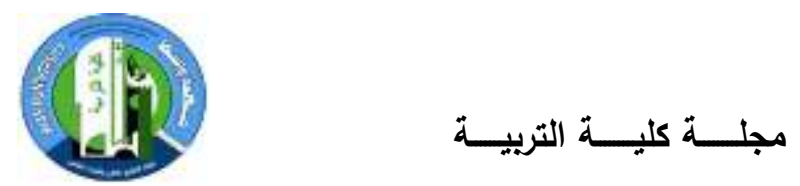

26. Cobye, A,"1987",Biological \& Psychological Adaptation and effected Factories ,Journal of Personality, Vol.12 ,No .9. Inc , American Psychological Association, U.S.A.

27. Cohen , P. M. \& Coulas , J. T. "1985" . Sensation seeking and Some Variables, Journal of Personality and Social Psychology, Vol. 48 , No. 1.

28. Cronbach,L.J,"1951": A coefficient Alpha and The internal Structure of Tests. Psychometrika.

29. DSM-IV-TR-TM ,"2000", Post Traumatic Stress Disorder "4ed." , Text Revision . American Psychiatric Association, Washington, DC .

30. Douclas A. Bernstein\& Peggy W. Nash,2005.Essintials of Psychology, 3ed, Houghton Mifflin Press, New York .

31. Ellis, Albert. "2007": Applications in Emotional-Mantel Psychotherapy Techniques, Trans-Hill. New York.

32. Researchers Team, 2004, The Survey Study for Iraqi Community, Michigan, U.S.A.

33. Erikson, Erik H, 2008 . Identity" You the and Crisis", W.W Northern and Company, Inc., New York.

34. Kattail, R,"1969", Introduction in Personality, Williams \& Wilkins , New York .

35. Kaplan, H. \& Sadock, B. J. "1998" . Concise textbook of Clinical Psychiatry, Williams \& Wilkins , New York .

36. Faiber,1958, Introduction in Sociology. Johen-Wiely, London.

37. Gabbard, G. O."2000". Psychodynamic psychiatry in clinical practice. 3ed., American Psychiatric Press , Inc. Washington

38. Harrison .A. "1983" Language testing I land. book, London the Macmillan press.

39. Helmstejter, G.C,1966. Principles of Physiological Measurement, Landon: Methuen \& Co. Ltd.

40. McClellan, D. B, "2006" . Longitudinal Research on drug use : Empirical findings and methodological issues, John Wiley \& sons, New York.

41. Rekhmier, M. "1988" Assessing coping strategies: A theoretically based approach. Journal of Personality and Social Psychology.

42. Researchers Team "ICD-12","2008" The World Guide Identification and Classification for Mental \& Psychological Disorders, "WHO", Geneva.

43. Sampthon.J,S."2001": The Social Deprivation As Consequence for Shocks Affairs" Survey in Third World Community", The Journal of Social Studies, Vol.6,No13. Durban-South Africa.

44. Stewart, B. J. "1992" .Social Imbed lance on Psychosocial Effects for Adolescents. Journal of Personality \&Social Psychology,Vol.14.No.6.British Psychological Association, Inc.

45. Tyler, L.N \& Walsh, W.B. "1979" Testing and Measurement, 3ed .New Jersey, Englewood, Cliffs :Prentice- Hall, Inc .

46. Winters , K.C."1996".Personal Experience Inventory for Adults Manual "PEI-A". Published by Western Psychological Services "WPS", Los Angeles. 
ملحق " ا"

"مقياسي المواساة الاجتماعية والتحمل النفسي بصورتهما الأولية"

الأستاذ الدكتور .................................

يعرض الباحث مشروع بحثه بدراسة المواساة الاجتماعية وعلاقتها بالتحمل النفسي للأحداث الصدمية الإرهابية

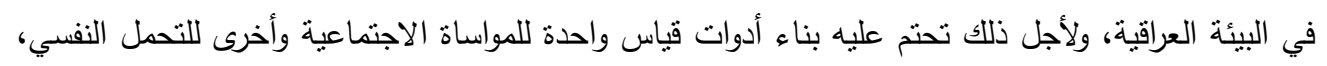
ولذا فإنهُ ينتع خطوات البناء كما منصوص عليها في مراجع القياس النفسي باشتقاق الفقرات من التعاريف المتبناة كما مرفقّ طياً، فقد تبنى تعريف أبوليلةو . . ب للمواساة الاجتماعية بأنها: "عملية اجتماعية شائعة

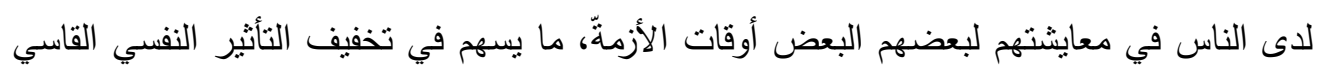
للحدثّ، ويتخذ ذلك التعايث أوجهٍ عدةّ فقد يكون بالكلام والزيارات المتكررة، أو عملياً كالمساهمة بالمال وما شابه".

وتعربف الغربري، 1 • بللتحل النفسي بأنهُ: "قدرة الفرد على مواجهة الضغوط الناجمة عن مواقف الحياة ومشكلاتها، إذّ ينتاب الفرد أثتائها أعراضاً نفسية كالتوتز والضيق نتراوح في الدرجة

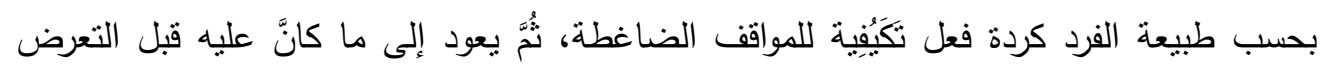
للموقف، ويختلف الأفراد في مستوى قدرتهم على التحمل تلك مثل باقي سمات الشخصية".

ولخبرتكم القيمة في مجال علم النفس يرجى بيان آرائكم في صلاحية فقرات المقياسين على قياس ما صُمَمَتِ لأجل قياسه، فضلاً عن التعليمات والبدائل التي كانت لمقياس المواساة الاجتماعية"أتفق نوعاً ما، أتفق، أثفق بثدة"، وبأوزان" ا-""، ولمقياس التحمل النفسي"تتطبق نوعاً ما، تتطبق، تتطبق

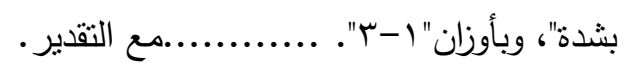


تعليمات مقياس المواساة الاجتماعية

$$
\text { أخي الكريم........أختي الكريمة }
$$

فيما يأتي عدد من الفقرات التي تستفسر عن رأيك بمشاركة الآخرين للكَّ أيام الأزمة،

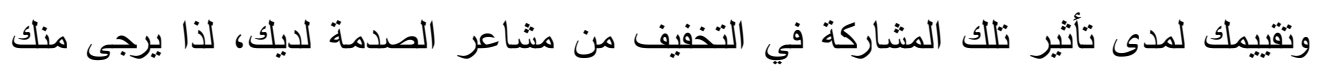

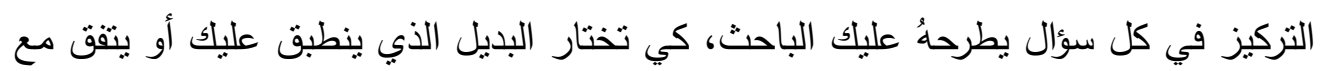

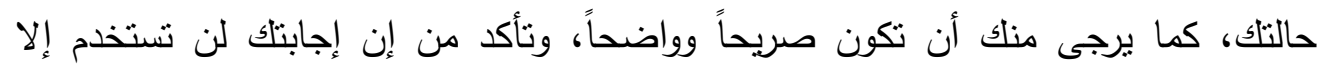
لأغراض البحث العلمي ولفائدته، علماً إنك لست مطالباً بذكر الإسم ... مع التقدير .

\section{الجنس}

العمر

التحصيل الاراسي

محل السكن

مستوى الاخل

مساحة الدار

السفر للخارج

اللغات التي تجيدها 


\section{مجلـــة كليـــة التربيـــة}

\section{تعليمات مقياس التحمل النفسي أخي الكريم........أختي الكريمة}

عادةً مـا يواجه الفرد في حياته مواقف صعبة، وفيما يأتي عدد من الفقرات التي تستفسر

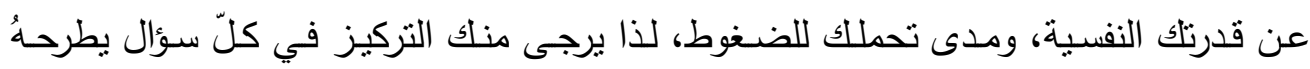

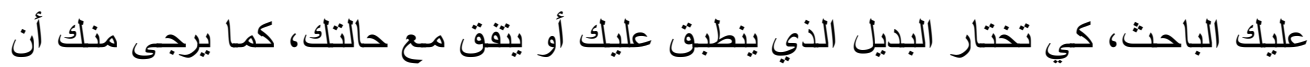

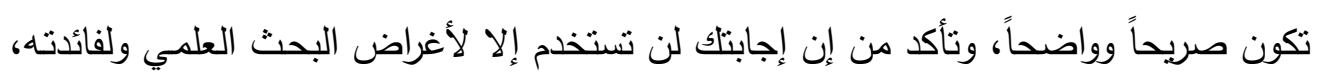
علماً أنك لست مطالباً بذكر الاسم.... مع التقدير .

\section{الباحث}




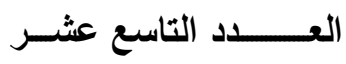

ملحق " ا، أ" مقياس المواساة الاجتماعية بصورته الأولية

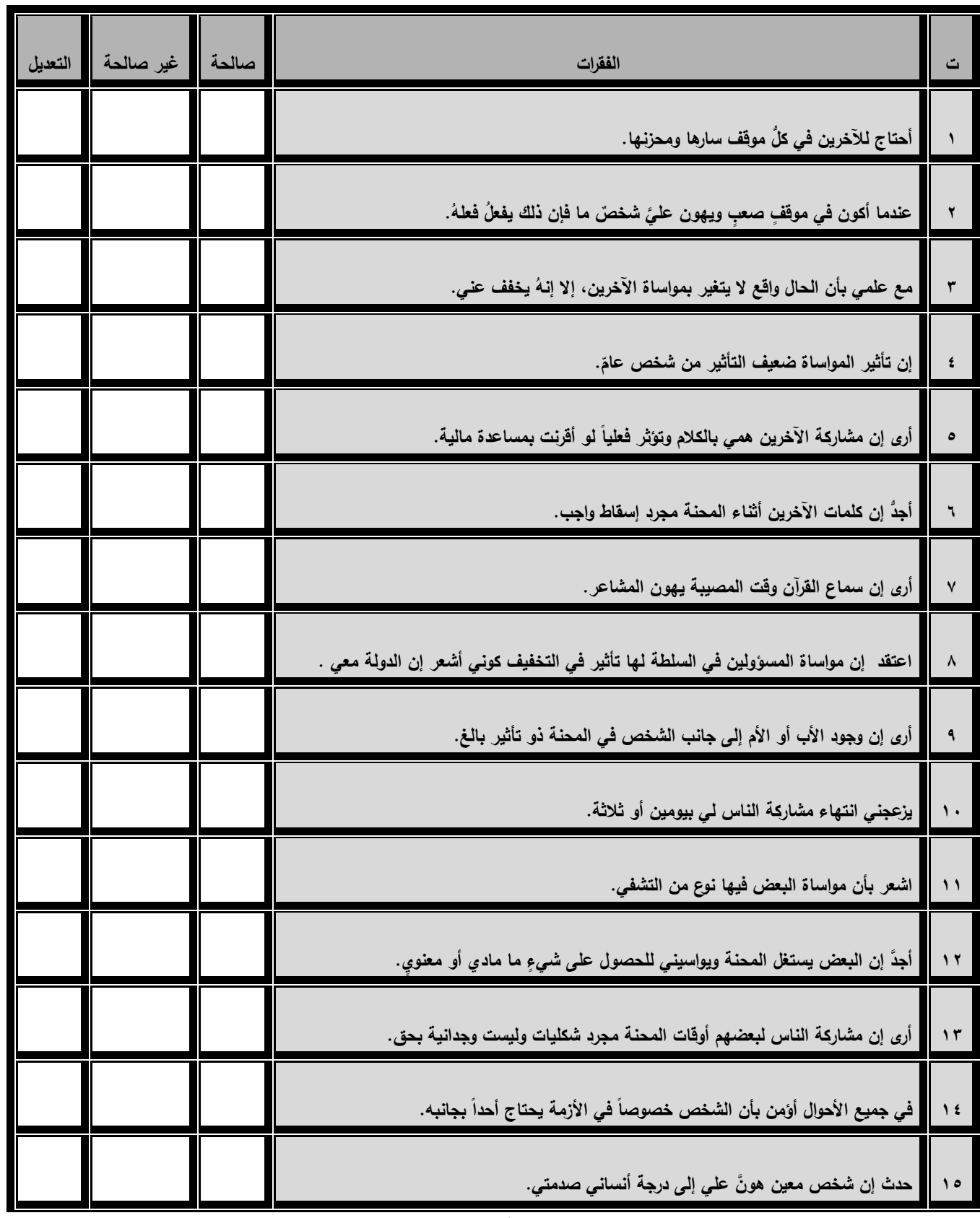




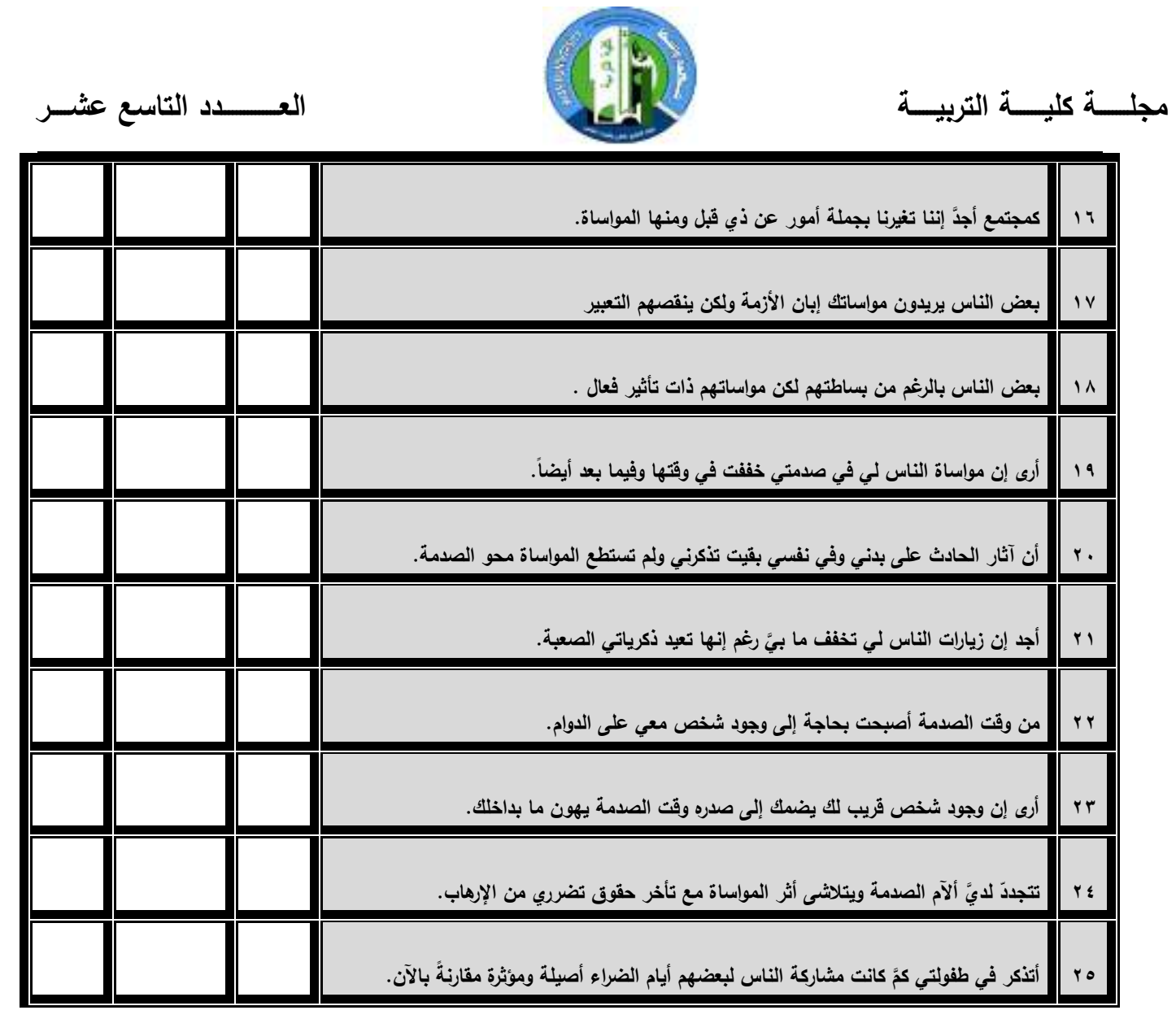

نيسان 10 
العــــــد التاسع عشــر

مجلــــة كليــــة التربيــــة

ملحق "ا، ب" مقياس التحمل النفسي بصورته الأولية

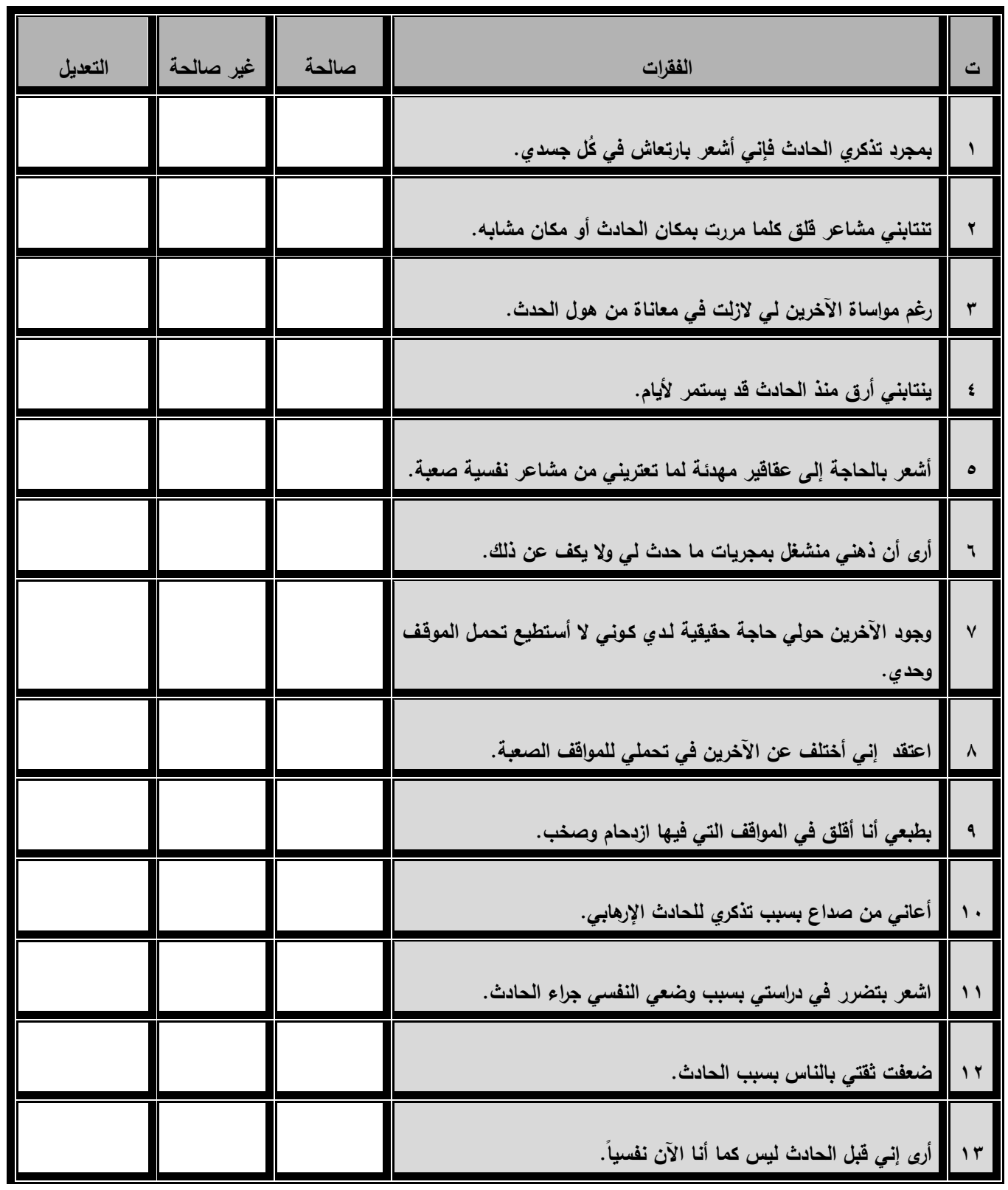




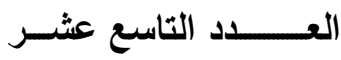

مجلــــة كليــــة التربيــــة

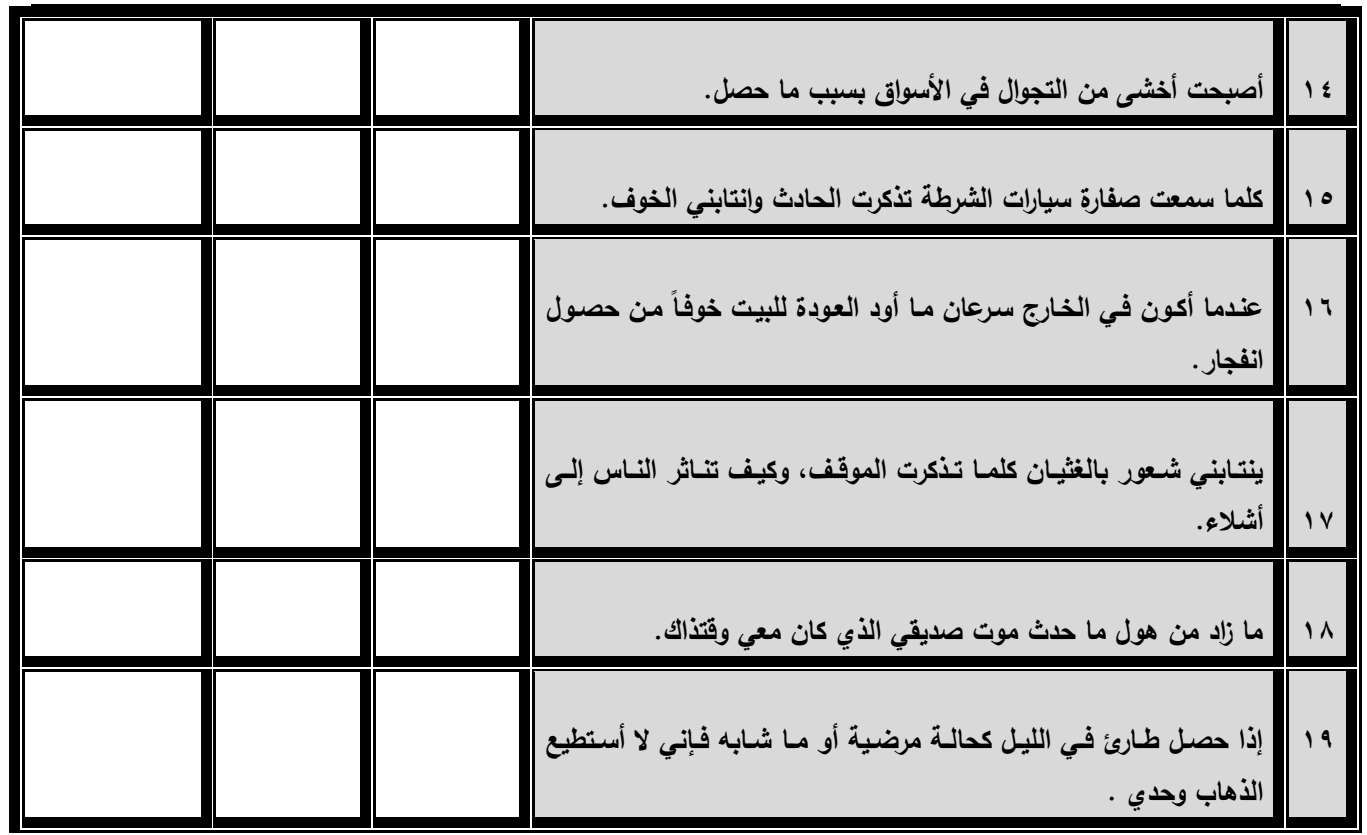


العــــــد التاسـع عشــر

مجلــــة كليــــة التربيــــة

ملحق "ץ، أ" مقياس المواساة الاجتماعية بصورته النهائية

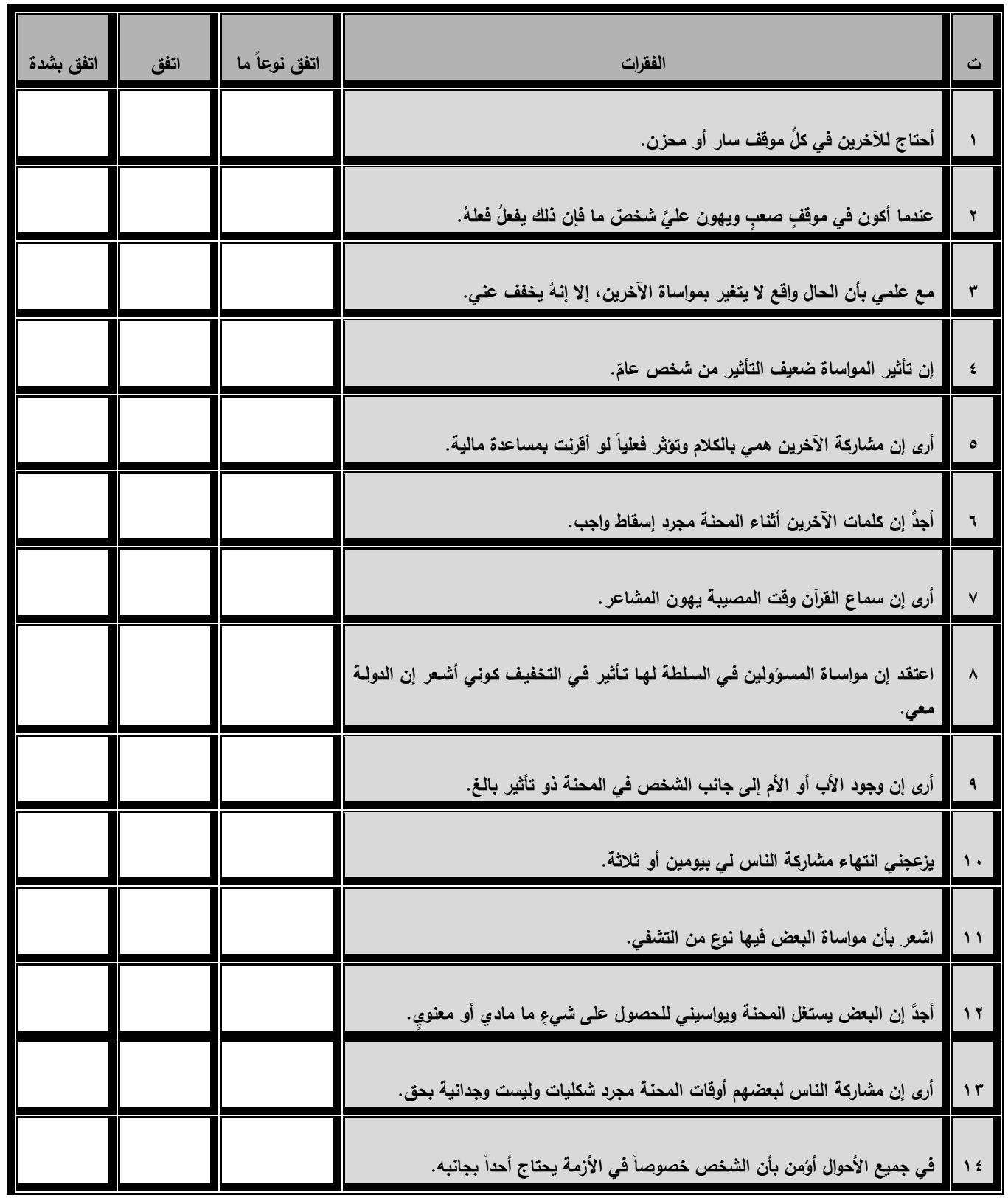

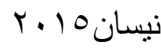




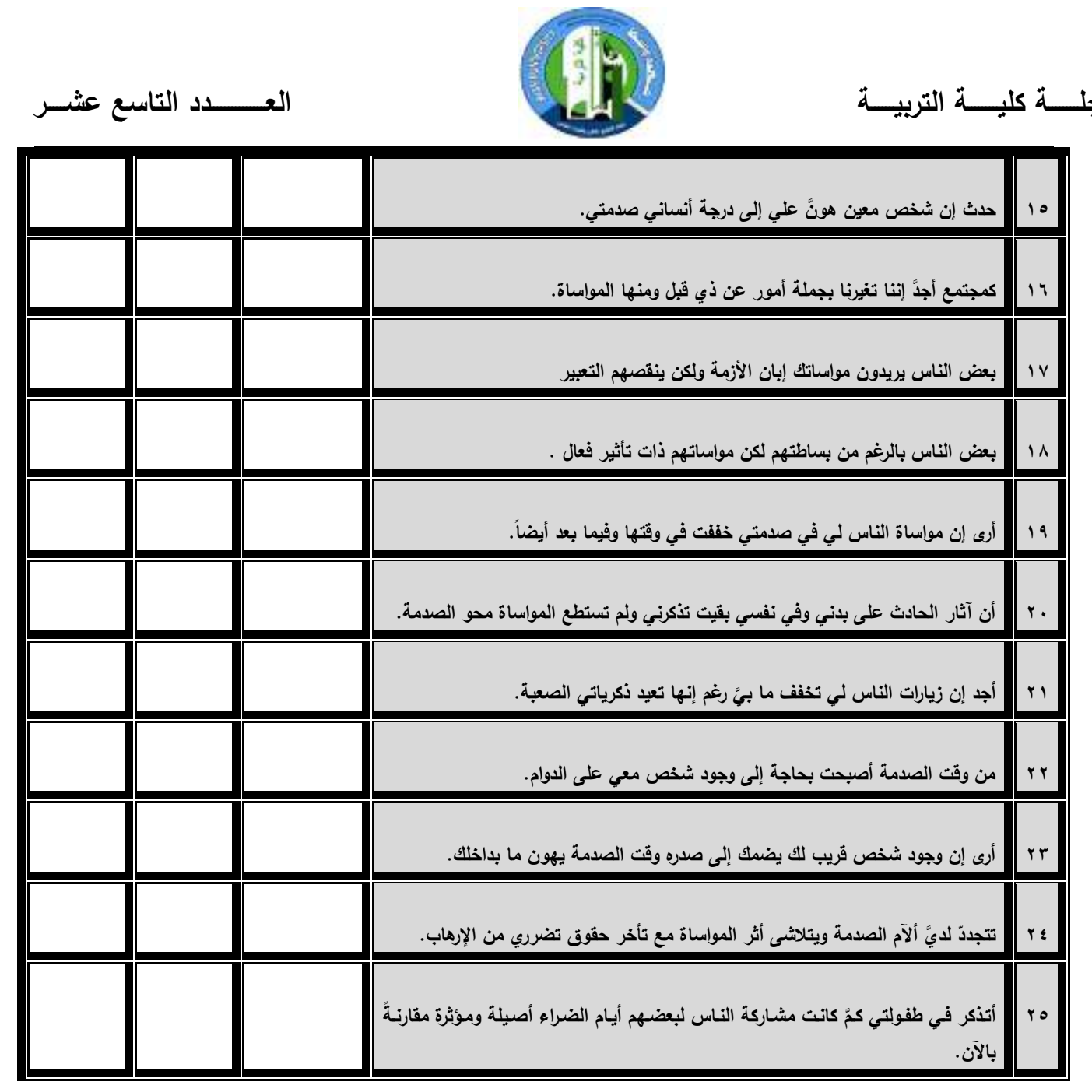

نيسان 10 
العــــــد التاسـع عشــر

ملحق "ץ، ب" مقياس التحمل النفسي بصورته النهائية

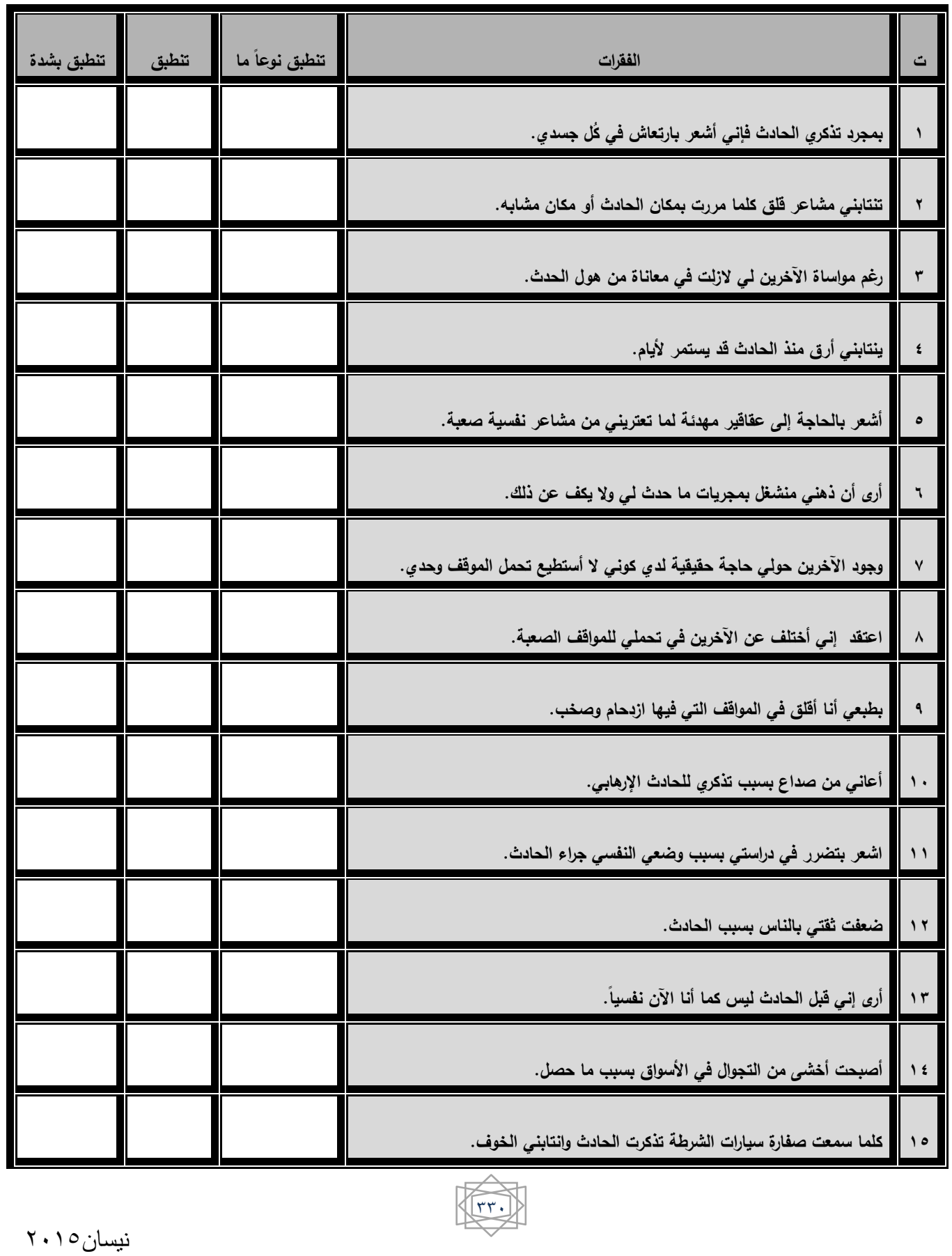




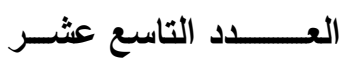

مجلــــة كليــــة التربيــــة

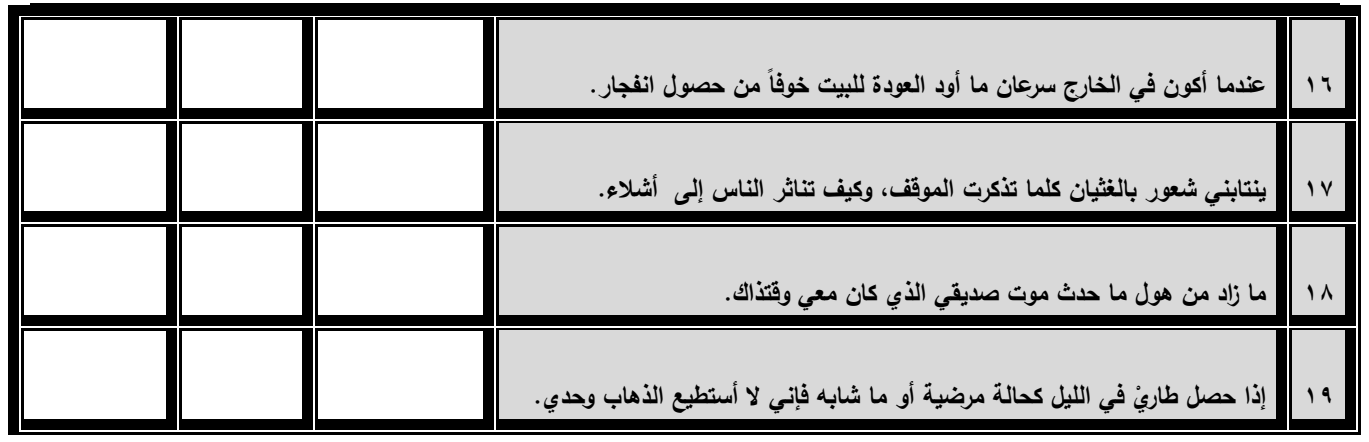

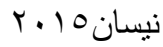




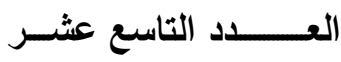

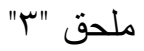

أسماء السادة الخبراء على صلاحية فقرات مقياسي المواساة الاجتماعية والتحمل النفسي

\begin{tabular}{|c|c|c|c|}
\hline موقع العمل & الارجة العلمية & 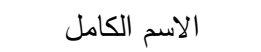 & ت \\
\hline قسم علم النفس/ آداب / جامعة بغداد & أ أ ـد & كامل علوان الزبيدي & 1 \\
\hline قسم علم النفس/ كلية التربية / الجامعة & أ أ ـد & 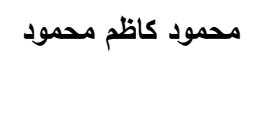 & r \\
\hline قسم الأبحاث النفسية/ جامعة بذاد & أ أ ـد & غسان سالم & $r$ \\
\hline قسم علم النفس / آداب / جامعة بغداد & أ أ ـد & بثينة منصور الحلو & $\varepsilon$ \\
\hline قسم علم النفس / آداب / جامعة ديالى & أ أ ـد & مهند عبد الستار & $\bullet$ \\
\hline قسم علم النفس/ آداب / جامعة بغداد & أ أ ـد & أروى محمد & 7 \\
\hline قسم علم النفس/ آداب / جامعة بغداد & أ أ.م .د & سناء مجول فيصل & V \\
\hline قسم علم النفس/ آداب / جامعة بغداد & أ أ.م . د & إبراهيم الأعرجي & $\wedge$ \\
\hline قسم علم النفس / آداب / جامعة بغداد & أ أم .د & فارس كمال عمر نظمي & 9 \\
\hline قسم علم النفس/ آداب / جامعة بغداد & أ أ.م . د & علي تركي نافل & 1. \\
\hline
\end{tabular}

